Atmos. Chem. Phys., 17, 11991-12010, 2017

https://doi.org/10.5194/acp-17-11991-2017

(C) Author(s) 2017. This work is distributed under

the Creative Commons Attribution 3.0 License.

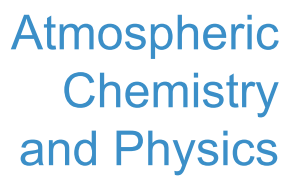

(c) (i)

\title{
Modeling of the chemistry in oxidation flow reactors with high initial NO
}

\author{
Zhe Peng and Jose L. Jimenez \\ Cooperative Institute for Research in Environmental Sciences and Department of Chemistry, University of Colorado, \\ Boulder, CO 80309, USA
}

Correspondence to: Zhe Peng (zhe.peng@ colorado.edu) and Jose L. Jimenez (jose.jimenez@ colorado.edu)

Received: 22 March 2017 - Discussion started: 10 April 2017

Revised: 28 August 2017 - Accepted: 4 September 2017 - Published: 10 October 2017

\begin{abstract}
Oxidation flow reactors (OFRs) are increasingly employed in atmospheric chemistry research because of their high efficiency of $\mathrm{OH}$ radical production from low-pressure $\mathrm{Hg}$ lamp emissions at both 185 and $254 \mathrm{~nm}$ (OFR185) or $254 \mathrm{~nm}$ only (OFR254). OFRs have been thought to be limited to studying low-NO chemistry (in which peroxy radicals $\left(\mathrm{RO}_{2}\right)$ react preferentially with $\left.\mathrm{HO}_{2}\right)$ because $\mathrm{NO}$ is very rapidly oxidized by the high concentrations of $\mathrm{O}_{3}, \mathrm{HO}_{2}$, and $\mathrm{OH}$ in OFRs. However, many groups are performing experiments by aging combustion exhaust with high NO levels or adding $\mathrm{NO}$ in the hopes of simulating high-NO chemistry (in which $\mathrm{RO}_{2}+\mathrm{NO}$ dominates). This work systematically explores the chemistry in OFRs with high initial NO. Using box modeling, we investigate the interconversion of $\mathrm{N}$ containing species and the uncertainties due to kinetic parameters. Simple initial injection of NO in OFR185 can result in more $\mathrm{RO}_{2}$ reacted with $\mathrm{NO}$ than with $\mathrm{HO}_{2}$ and minor non-tropospheric photolysis, but only under a very narrow set of conditions (high water mixing ratio, low UV intensity, low external $\mathrm{OH}$ reactivity $\left(\mathrm{OHR}_{\text {ext }}\right)$, and initial $\mathrm{NO}$ concentration $\left(\mathrm{NO}^{\mathrm{in}}\right)$ of tens to hundreds of $\mathrm{ppb}$ ) that account for a very small fraction of the input parameter space. These conditions are generally far away from experimental conditions of published OFR studies with high initial NO. In particular, studies of aerosol formation from vehicle emissions in OFRs often used $\mathrm{OHR}_{\text {ext }}$ and $\mathrm{NO}^{\text {in }}$ several orders of magnitude higher. Due to extremely high $\mathrm{OHR}_{\mathrm{ext}}$ and $\mathrm{NO}^{\text {in }}$, some studies may have resulted in substantial non-tropospheric photolysis, strong delay to $\mathrm{RO}_{2}$ chemistry due to peroxynitrate formation, $\mathrm{VOC}$ reactions with $\mathrm{NO}_{3}$ dominating over those with $\mathrm{OH}$, and faster reactions of $\mathrm{OH}$-aromatic adducts with $\mathrm{NO}_{2}$ than those with $\mathrm{O}_{2}$, all of which are irrelevant to am-
\end{abstract}

bient VOC photooxidation chemistry. Some of the negative effects are the worst for alkene and aromatic precursors. To avoid undesired chemistry, vehicle emissions generally need to be diluted by a factor of $>100$ before being injected into an OFR. However, sufficiently diluted vehicle emissions generally do not lead to high-NO chemistry in OFRs but are rather dominated by the low- $\mathrm{NO} \mathrm{RO}_{2}+\mathrm{HO}_{2}$ pathway. To ensure high-NO conditions without substantial atmospherically irrelevant chemistry in a more controlled fashion, new techniques are needed.

\section{Introduction}

The oxidation of gases that are emitted into the atmosphere, in particular volatile organic compounds (VOCs), is one of the most important atmospheric chemistry processes (Haagen-Smit, 1952; Chameides et al., 1988). VOC oxidation is closely related to radical production and consumption (Levy II, 1971), $\mathrm{O}_{3}$ production, and the formation of secondary aerosols (Odum et al., 1996; Hoffmann et al., 1997; Volkamer et al., 2006; Hallquist et al., 2009), which have impacts on air quality and climate (Lippmann, 1991; Nel, 2005; Stocker et al., 2014).

Chemical reactors are critical tools for research of VOC oxidation. Oxidation reactions of interest often have typical timescales of hours to weeks. Studying these processes in ambient air can be confounded by dispersion and changes in ambient conditions, which often occur on similar timescales. Chemical reactors allow for the decoupling of these two types of processes. Also, they should be able to simulate the different regimes of reactions occurring in the atmosphere, 
e.g., VOC oxidation under the low- and high-NO conditions (peroxy radical fate dominated by reaction with $\mathrm{HO}_{2}$ or $\mathrm{NO}$ ) representing remote and urban areas, respectively (Orlando and Tyndall, 2012).

Large environmental chambers are a commonly used reactor type (Carter et al., 2005; Wang et al., 2011). They typically employ actinic wavelength $(>300 \mathrm{~nm})$ light sources (e.g., outdoor solar radiation and UV black lights) to produce oxidants and radicals and have large volumes (on the order of several cubic meters or larger). However, the capability of generating sustained elevated levels of $\mathrm{OH}$, the most important tropospheric oxidant, is usually limited in chambers, resulting in $\mathrm{OH}$ concentrations similar to those in the atmosphere $\left(10^{6}-10^{7}\right.$ molecules $\mathrm{cm}^{-3}$; Mao et al., 2009; $\mathrm{Ng}$ et al., 2010) and consequently long simulation times (typically hours) to reach $\mathrm{OH}$ equivalent ages of atmospheric relevance (George et al., 2007; Kang et al., 2007; Carlton et al., 2009; Seakins, 2010; Wang et al., 2011). The partitioning of gases and aerosols to chamber walls (usually made of Teflon) in timescales of tens of minutes to hours makes it difficult to conduct very long experiments that simulate high atmospherically relevant photochemical ages (Cocker et al., 2001; Matsunaga and Ziemann, 2010; Zhang et al., 2014; Krechmer et al., 2016). In addition, the long simulation times and large size of chambers and auxiliary equipment are logistically difficult for field deployment, and their cost limits the number of laboratories equipped with them.

Given the limitations of environmental chambers, a growing number of experimenters have instead employed oxidation flow reactors (OFRs). OFRs have a much smaller size (on the order of $10 \mathrm{~L}$ ), efficiently generate $\mathrm{OH}$ via photolysis of $\mathrm{H}_{2} \mathrm{O}$ and/or $\mathrm{O}_{3}$ by more energetic 185 and $254 \mathrm{~nm}$ photons from low-pressure $\mathrm{Hg}$ lamps, and overcome the abovementioned shortcomings of chambers due to a much shorter residence time (George et al., 2007; Kang et al., 2007, 2011; Lambe et al., 2011). Moreover, OFRs are able to rapidly explore a wide range of $\mathrm{OH}$ equivalent ages within a short period $(\sim 2 \mathrm{~h})$ during which significant changes in ambient conditions can usually be avoided in the case of field deployment (Ortega et al., 2016; Palm et al., 2016, 2017). Because of these advantages, OFRs have recently been widely used to study atmospheric chemistry, in particular secondary organic aerosol (SOA) formation and aging, in both the laboratory and the field (Kang et al., 2011; Li et al., 2013; Ortega et al., 2013, 2016; Tkacik et al., 2014; Palm et al., 2016).

In addition to experimental studies using OFRs, there has also been some progress in the characterization of OFR chemistry by modeling. Li et al. (2015) and Peng et al. (2015) developed a box model for OFR $\mathrm{HO}_{x}$ chemistry that predicts measurable quantities (e.g., $\mathrm{OH}$ exposure, $\mathrm{OH}_{\text {exp }}$, in molecules $\mathrm{cm}^{-3} \mathrm{~s}$ and $\mathrm{O}_{3}$ concentration, abbr. $\mathrm{O}_{3}$ hereinafter, in ppm) in good agreement with experiments. This model has been used to characterize $\mathrm{HO}_{x}$ chemistry as a function of $\mathrm{H}_{2} \mathrm{O}$ mixing ratio (abbr. $\mathrm{H}_{2} \mathrm{O}$ hereinafter, unitless), UV light intensity (abbr. UV hereinafter, in photons $\mathrm{cm}^{-2} \mathrm{~s}^{-1}$ ), and external $\mathrm{OH}$ reactivity (in $\mathrm{s}^{-1}, \mathrm{OHR}_{\mathrm{ext}}=, \sum k_{i} c_{i}$, i.e., the sum of the products of concentrations of externally introduced $\mathrm{OH}$-consuming species, $c_{i}$, and rate constants of their reactions with $\mathrm{OH}, k_{i}$ ). Based on this characterization, Peng et al. (2015) found that $\mathrm{OH}$ suppression, i.e., the reduction of $\mathrm{OH}$ concentration caused by $\mathrm{OHR}_{\mathrm{ext}}$, is a common feature under many typical OFR operation conditions. Peng et al. (2016) systematically examined the relative importance of non-OH (including non-tropospheric) reactants in the fate of VOCs over a wide range of conditions and provided guidelines for OFR operation to avoid non-tropospheric VOC photolysis, i.e., VOC photolysis at 185 and $254 \mathrm{~nm}$.

In previous OFR modeling studies, $\mathrm{NO}_{x}$ chemistry was not investigated in detail since in such in typical OFR experiments with large amounts of oxidants (e.g., $\mathrm{OH}, \mathrm{HO}_{2}$, and $\mathrm{O}_{3}$ ) NO would be very rapidly oxidized and thus unable to compete with $\mathrm{HO}_{2}$ for reaction with peroxy radicals $\left(\mathrm{RO}_{2}\right)$. $\mathrm{Li}$ et al. (2015) estimated an $\mathrm{NO}\left(\mathrm{NO}_{2}\right)$ lifetime of $\sim 0.5$ $(\sim 1.5)$ s under a typical OFR condition. From these estimates, OFRs processing ambient air or laboratory air without a large addition of $\mathrm{NO}_{x}$ were assumed to not be suitable for studying oxidation mechanisms relevant to polluted conditions under higher NO concentrations. OFRs have recently been used to conduct laboratory experiments with very high initial $\mathrm{NO}_{x}$ levels (Liu et al., 2015) and deployed to an urban tunnel where $\mathrm{NO}_{x}$ was high enough to be a major $\mathrm{OH}$ reactant (Tkacik et al., 2014). The former study reported evidence for the incorporation of nitrogen into SOA. OFRs have also been increasingly employed to process emissions of vehicles, biomass burning, and other combustion sources (Table 1) in which NO can often be hundreds of ppm (Ortega et al., 2013; Martinsson et al., 2015; Karjalainen et al., 2016; Link et al., 2016; Schill et al., 2016; Alanen et al., 2017; Simonen et al., 2017). It can be expected that such a high NO input together with very high VOC concentrations would cause a substantial deviation from the good OFR operation conditions identified in Peng et al. (2016). Very recently, $\mathrm{N}_{2} \mathrm{O}$ injection has been proposed by Lambe et al. (2017) as a way to study the oxidation of VOCs under high NO conditions in an OFR. As more OFR studies at high $\mathrm{NO}_{x}$ levels are conducted, there is a growing need to understand the chemistry of $\mathrm{N}$-containing species in OFRs and whether it proceeds along atmospherically relevant channels.

In this study, we present the first comprehensive model of OFR $\mathrm{NO}_{y}$ chemistry. We extend the model of Li et al. (2015) and Peng et al. (2015) by including a scheme for $\mathrm{NO}_{y}$ species. Then this model is used to investigate (i) whether an OFR with initial NO injection results in NO significantly reacting with $\mathrm{RO}_{2}$ under any conditions, (ii) whether previously published OFR experiments with high initial NO concentrations led to $\mathrm{RO}_{2}+\mathrm{NO}$ being dominant in VOC oxidation without negative side effects (e.g., non-tropospheric reactions), and iii) how to avoid undesired chemistry in future studies. The results can provide insights into the design and 
Table 1. Experimental conditions of several OFR studies with high NO injection.

\begin{tabular}{llcrrrr}
\hline Study & Source type & $\begin{array}{c}\text { Temperature } \\
(\mathrm{K})\end{array}$ & $\begin{array}{r}\text { Relative } \\
\text { humidity } \\
(\%)\end{array}$ & $\begin{array}{r}\text { Dilution } \\
\text { factor }\end{array}$ & $\begin{array}{r}\text { External OH } \\
\text { reactivity } \\
\text { of undiluted } \\
\text { source }\left(\mathrm{s}^{-1}\right)\end{array}$ & $\begin{array}{r}\text { Source } \mathrm{NO}_{x} \\
\text { concentration } \\
(\mathrm{ppm})\end{array}$ \\
\hline Link et al. (2016) & Diesel vehicle emission & & 50 & $45-110$ & $\sim 5000^{1}$ & $436^{1}$ \\
Martinsson et al. (2015) & Biomass burning emission & & & 1700 & $156400^{1}$ & 154 \\
Karjalainen et al. (2016) & Gasoline vehicle emission & 295 & 60 & 12 & $\sim 73000^{2, \mathrm{a}}$ & $\sim 400^{1, \mathrm{~b}}$ \\
Liu et al. (2015) & Purified gas & 293 & 13 & 1 & $\sim 1400^{1, \mathrm{a}}$ & $10^{1, \mathrm{~b}}$ \\
Tkacik et al. (2014) & Tunnel air & 293 & 42 & 1 & $\sim 60^{1, \mathrm{a}}$ & $\sim 0.8^{1}$ \\
Ortega et al. (2013) & Biomass burning emission & 290 & 30 & $\sim 500$ & $\sim 250000^{1}$ & $\sim 0.2$ \\
\hline
\end{tabular}

${ }^{1}$ Maximum value in the study; ${ }^{2}$ value at the moment of maximum $\mathrm{NO}$ emission; ${ }^{\mathrm{a}} \mathrm{NO} y$ species excluded; ${ }^{\mathrm{b}} \mathrm{NO}$ only.

interpretation of future $\mathrm{OH}$-oxidation OFR experiments with large amounts of $\mathrm{NO}_{x}$ injection.

\section{Methods}

The physical design of the OFR modeled in the present work, the chemical kinetics box model, and the method of propagating and analyzing the parametric uncertainties on the model have already been introduced previously (Kang et al., 2007; Li et al., 2015; Peng et al., 2015). We only provide brief descriptions for them below.

\subsection{Potential aerosol mass flow reactor}

The OFR modeled in this study is the potential aerosol mass (PAM) flow reactor first introduced by Kang et al. (2007). The PAM OFR is a cylindrical vessel with a volume of $\sim 13 \mathrm{~L}$, equipped with low-pressure $\mathrm{Hg}$ lamps (model no. 82-9304-03; BHK Inc.) to generate 185 and $254 \mathrm{~nm}$ UV light. This popular design is being used by many atmospheric chemistry research groups, particularly those studying SOA (Lambe and Jimenez, 2017 and references therein). When the lamps are mounted inside Teflon sleeves, photons at both wavelengths are transmitted and contribute to $\mathrm{OH}$ production (OFR185 mode). In OFR185, $\mathrm{H}_{2} \mathrm{O}$ photolyzed at $185 \mathrm{~nm}$ produces $\mathrm{OH}$ and $\mathrm{HO}_{2}$, while $\mathrm{O}_{2}$ photolyzed at the same wavelengths results in $\mathrm{O}_{3}$ formation. $\mathrm{O}\left({ }^{1} \mathrm{D}\right)$ is produced via $\mathrm{O}_{3}$ photolysis at $254 \mathrm{~nm}$ and generates additional $\mathrm{OH}$ through its reaction with $\mathrm{H}_{2} \mathrm{O}$. The $185 \mathrm{~nm}$ lamp emissions can be filtered by mounting the lamps inside quartz sleeves, leaving only $254 \mathrm{~nm}$ photons to produce $\mathrm{OH}$ (OFR254 mode). In this mode, injection of externally formed $\mathrm{O}_{3}$ is necessary to ensure $\mathrm{OH}$ production. As the amount of $\mathrm{O}_{3}$ injected is a key parameter under some conditions (Peng et al., 2015), we adopt the notation OFR254-X to denote OFR254 experiments with $\mathrm{X}$ ppm initial $\mathrm{O}_{3}\left(\mathrm{O}_{3}\right.$,in $)$. In this study, we investigate OFR experiments with NO injected and thus utilize "OFR185-iNO" to describe the OFR185 mode of operation with initially (at the reactor entrance) injected NO.
The same terminology is used for the OFR254 mode. For instance, the initial NO injection into OFR254-7 is denoted as OFR254-7-iNO.

\subsection{Model description}

The basic framework of the box model used in this study, a standard chemical kinetics model, is the same as in Peng et al. (2015). Plug flow is assumed in the model, since approximately taking residence time distribution into account leads to similar results under most conditions but at much higher computational expense (Peng et al., 2015). In addition to the reactions in the model of Peng et al. (2015) including all $\mathrm{HO}_{x}$ reactions available in the JPL Chemical Kinetic Data Evaluation (Sander et al., 2011), all gas-phase $\mathrm{NO}_{y}$ reactions available in the JPL database except those of organic nitrates and peroxynitrates are also considered in the current reaction scheme. An updated JPL evaluation was published recently (Burkholder et al., 2015) with slightly different $(\sim 20 \%)$ rate constants for $\mathrm{NO}_{2}+\mathrm{HO}_{2}+\mathrm{M} \rightarrow \mathrm{HO}_{2} \mathrm{NO}_{2}+\mathrm{M}$ and $\mathrm{NO}_{2}+\mathrm{NO}_{3} \rightarrow \mathrm{N}_{2} \mathrm{O}_{5}$. The updated rate constants only result in changes of $\sim 10-20 \%$ in the concentrations of the species directly consumed or produced by these reactions. These changes are smaller than the parametric uncertainties of the model (see Sect. 3.1.3). For other species, concentration changes are negligible. $\mathrm{HO}_{2} \mathrm{NO}_{2}+\mathrm{M} \rightarrow \mathrm{HO}_{2}+\mathrm{NO}_{2}+\mathrm{M}$ and $\mathrm{N}_{2} \mathrm{O}_{5}+\mathrm{M} \rightarrow \mathrm{NO}_{2}+\mathrm{NO}_{3}+\mathrm{M}$, are also included in the scheme with kinetic parameters from the IUPAC Task Group on Atmospheric Chemical Kinetic Data Evaluation (Ammann et al., 2016). As in Peng et al. (2015, 2016), $\mathrm{SO}_{2}$ is used as a surrogate for external $\mathrm{OH}$ reactants (e.g., VOCs). $\mathrm{NO}_{y}$ species, although also external $\mathrm{OH}$ reactants, are explicitly treated in the model and not counted in $\mathrm{OHR}_{\mathrm{ext}}$ in this work. Therefore, $\mathrm{OHR}_{\mathrm{ext}}$ stands for $n o n-\mathrm{NO}_{y} \mathrm{OHR}_{\mathrm{ext}}$ only hereinafter unless otherwise stated.

Also, particle-phase chemistry and physical and chemical interactions of gas-phase species with particles are not considered in this study. We have made this assumption because of the following. 
i. The presence of aerosols has typically negligible impacts on the gas-phase chemistry of radicals, $\mathrm{NO}_{y}$, and the $\mathrm{OH}$ reactants studied here. The condensational sink (CS) of ambient aerosols can rarely exceed $1 \mathrm{~s}^{-1}$ even in polluted areas and is usually $1-3$ orders of magnitude lower (Donahue et al., 2016; Palm et al., 2016). Thus, even under the assumption of unity uptake coefficient, CS cannot compete with $\mathrm{OHR}_{\text {ext }}$ (usually on the order of $10 \mathrm{~s}^{-1}$ or higher) in $\mathrm{OH}$ loss. Uptake of $\mathrm{NO}$ onto aerosols only occurs through the reaction with $\mathrm{RO}_{2}$ on the particle surface (Richards-Henderson et al., 2015), which is formed very slowly (see below) compared to gas-phase $\mathrm{HO}_{x}$ and $\mathrm{NO}_{x}$ chemistry. Uptake of $\mathrm{HO}_{2}, \mathrm{O}_{3}$, $\mathrm{NO}_{3}$, etc. is even more unlikely to be of importance due to lower uptake coefficients (Moise and Rudich, 2002; Moise et al., 2002; Hearn and Smith, 2004; Lakey et al., 2015). Combustion exhausts can have high aerosol loadings with condensational sinks on the order of $10^{2}$ $10^{3} \mathrm{~s}^{-1}$ (Matti Maricq, 2007). Even if these exhausts are directly injected into the reactor without any pretreatment, uptake onto the particles still cannot play a major role in the fate of gas-phase radical and $\mathrm{NO}_{x}$ species since VOCs and $\mathrm{NO}_{x}$ in raw exhausts, which are proportionally orders of magnitude higher, still dominate the fate of oxidants. Dilution of combustion emissions simultaneously lowers condensational sinks and the sinks of oxidants due to chemical reactions with their relative importance remaining the same as in undiluted emissions.

ii. Gas-phase radical and $\mathrm{NO}_{y}$ species only has limited impacts on OA chemistry in this study. The heterogeneous oxidation of $\mathrm{OA}$ by $\mathrm{OH}$ is generally slow. Significant OA loss due to heterogeneous oxidation can only be seen at photochemical ages as high as weeks (Hu et al., 2016). The enhancement of heterogeneous oxidation due to $\mathrm{NO}$ is remarkable only at $\mathrm{OH}$ concentrations close to the ambient values but not at typical values in an OFR (Richards-Henderson et al., 2015).

It is well known that the aerosol concentration can have a major impact on the physical uptake of semivolatile and lowvolatility gas-phase species. However, this process is not explicitly modeled in this study.

As $\mathrm{OHR}_{\text {ext }}$ plays a major and even dominant role in $\mathrm{OH}$ loss, it is an important approximation that the real $\mathrm{OHR}_{\mathrm{ext}}$ decay (due to primary VOC oxidation and subsequent oxidation of higher-generation products) is surrogated by that of $\mathrm{SO}_{2}$ (see Fig. S2 of Peng et al., 2015). Gas-phase measurements in the literature on laboratory studies revealed that there is large variability in the evolution of total $\mathrm{OHR}_{\text {ext }}$ during the oxidation of primary VOCs and subsequent oxidation of their intermediate products depending on the type of precursors (Nehr et al., 2014; Schwantes et al., 2017). This variability is clearly mainly due to the formation of different types and amounts of oxidation intermediates and products contributing to $\mathrm{OHR}_{\text {ext }}$. This variation is highly complex due to the large number of possible oxidation intermediates and the limited knowledge of detailed higher-generation mechanisms, and thus it is difficult to accurately capture even if modeling with a mechanism as explicit as the Master Chemical Mechanism (Schwantes et al., 2017). Therefore, it is justified to use a lumped surrogate to model the $\mathrm{OHR}_{\text {ext }}$ decay for simplicity and efficiency. This approximation is a substantial contributor to the uncertainty in our model. The uncertainties due to the types of oxidation intermediates and products are very likely larger than those due to mass transfer processes between gas and particle phases, wall losses, etc., which are not considered in this study.

A residence time of $180 \mathrm{~s}$ and the typical temperature $(295 \mathrm{~K})$ and atmospheric pressure $(835 \mathrm{mbar})$ in Boulder, CO, USA are assumed for all model cases. The lower-thansea-level pressure only leads to minor differences in the outputs ( $\mathrm{Li}$ et al., 2015). We explore physical input cases evenly spaced in a logarithmic scale over very wide ranges: $\mathrm{H}_{2} \mathrm{O}$ of $0.07-2.3 \%$, i.e., relative humidity (RH) of $2-71 \%$ at $295 \mathrm{~K} ; 185 \mathrm{~nm} \mathrm{UV}$ of $1.0 \times 10^{11}-1.0 \times 10^{14}$ and $254 \mathrm{~nm}$ $\mathrm{UV}$ of $4.2 \times 10^{13}-8.5 \times 10^{15}$ photons cm $\mathrm{cm}^{-2} \mathrm{~s}^{-1}$; $\mathrm{OHR}_{\mathrm{ext}}$ of $1-16000 \mathrm{~s}^{-1} ; \mathrm{O}_{3, \text { in }}$ of $2.2-70 \mathrm{ppm}$ for OFR254; and initial $\mathrm{NO}$ mixing ratio $\left(\mathrm{NO}^{\mathrm{in}}\right)$ from $10 \mathrm{ppt}$ to $40 \mathrm{ppm}$. Conditions with $\mathrm{OHR}_{\text {ext }}=0$ are also explored. UV at $254 \mathrm{~nm}$ is estimated from that at $185 \mathrm{~nm}$ according to the relationship determined by Li et al. (2015). Several typical cases within this range and their corresponding four- or two-character labels (e.g., MMOV and HL) are defined in Table 2. Literature studies are modeled by adopting all reported parameters (e.g., residence time, $\mathrm{H}_{2} \mathrm{O}$, and $\mathrm{O}_{3}$,in ) and estimating any others that may be needed (e.g., UV) from the information provided in the papers.

In this study, $\mathrm{OH}$ equivalent ages are calculated under the assumption of an ambient $\mathrm{OH}$ concentration of $1.5 \times 10^{6}$ molecules $\mathrm{cm}^{-3}$ (Mao et al., 2009). Conditions leading to a ratio of $\mathrm{RO}_{2}$ reacted with $\mathrm{NO}$ over the entire residence time $\left[r\left(\mathrm{RO}_{2}+\mathrm{NO}\right)\right]$ to that with $\mathrm{HO}_{2}$ $\left[r\left(\mathrm{RO}_{2}+\mathrm{HO}_{2}\right)\right]$ larger than 1 are regarded as "high NO" (under the assumption of constant $\mathrm{OHR}_{\mathrm{ext}}$ from VOCs; see Sect. S1 for more details), where $[r(X)]$ is the total reactive flux for reaction $X$ over the entire residence time. $\mathrm{F} 185_{\exp } / \mathrm{OH}_{\exp }$ and $\mathrm{F} 254_{\exp } / \mathrm{OH}_{\exp }$ are used as measures of the relative importance of VOC photolysis at 185 and $254 \mathrm{~nm}$ to their reactions with $\mathrm{OH}$, respectively; F185 exp (F254 exp) are 185 (254) nm photon flux exposure, i.e., the product of $185(254) \mathrm{nm}$ photon flux and time. Readers may refer to Figs. 1 and 2 of Peng et al. (2016) for the determination of the relative importance of nontropospheric (185 and $254 \mathrm{~nm}$ ) photolysis of individual VOCs. Although the relative importance of non-tropospheric photolysis depends on individual VOCs, in the present work, we set criteria on $\mathrm{F} 185_{\exp } / \mathrm{OH}_{\exp }<3 \times 10^{3} \mathrm{~cm} \mathrm{~s}^{-1}$ and $\mathrm{F} 254_{\exp } / \mathrm{OH}_{\exp }<4 \times 10^{5} \mathrm{~cm} \mathrm{~s}^{-1}$ to define "good" conditions and $\mathrm{F} 185_{\exp } / \mathrm{OH}_{\exp }<1 \times 10^{5} \mathrm{~cm} \mathrm{~s}^{-1}$ and 
Table 2. Code of the labels of typical cases. A case label can be composed of four characters denoting the water mixing ratio, the photon flux, the external $\mathrm{OH}$ reactivity excluding $\mathrm{N}$-containing species, and the initial NO mixing ratio. A case label can also be composed of two characters denoting the water mixing ratio and the photon flux.

\begin{tabular}{|c|c|c|c|c|}
\hline & $\begin{array}{l}\text { Water mixing } \\
\text { ratio }\end{array}$ & Photon flux & $\begin{array}{l}\text { External } \mathrm{OH} \\
\text { reactivity } \\
(\text { no } \mathrm{ON})\end{array}$ & $\begin{array}{l}\text { Initial NO } \\
\text { mixing } \\
\text { ratio }\end{array}$ \\
\hline \multirow{4}{*}{ Options } & $\begin{array}{l}L=\text { low } \\
(0.07 \%)\end{array}$ & $\begin{array}{l}L=\text { low }\left(10^{11} \text { photons } \mathrm{cm}^{-2} \mathrm{~s}^{-1} \text { at } 185 \mathrm{~nm}\right. \\
\left.4.2 \times 10^{13} \text { photons } \mathrm{cm}^{-2} \mathrm{~s}^{-1} \text { at } 254 \mathrm{~nm}\right)\end{array}$ & 0 & 0 \\
\hline & $\begin{array}{l}M=\text { medium } \\
(1 \%)\end{array}$ & $\begin{array}{l}M=\text { medium }\left(10^{13} \text { photons } \mathrm{cm}^{-2} \mathrm{~s}^{-1} \text { at } 185 \mathrm{~nm}\right. \\
\left.1.4 \times 10^{15} \text { photons } \mathrm{cm}^{-2} \mathrm{~s}^{-1} \text { at } 254 \mathrm{~nm}\right)\end{array}$ & $\begin{array}{l}L=\text { low } \\
\left(10 \mathrm{~s}^{-1}\right)\end{array}$ & $\begin{array}{l}L=\text { low } \\
(10 \mathrm{ppb})\end{array}$ \\
\hline & $\begin{array}{l}H=\text { high } \\
(2.3 \%)\end{array}$ & $\begin{array}{l}H=\text { high }\left(10^{14} \text { photons } \mathrm{cm}^{-2} \mathrm{~s}^{-1} \text { at } 185 \mathrm{~nm}\right. \\
\left.8.5 \times 10^{15} \text { photons } \mathrm{cm}^{-2} \mathrm{~s}^{-1} \text { at } 254 \mathrm{~nm}\right)\end{array}$ & $\begin{array}{l}H=\text { high } \\
\left(100 s^{-1}\right)\end{array}$ & $\begin{array}{l}H=\text { high } \\
(316 \mathrm{ppb})\end{array}$ \\
\hline & & & $\begin{array}{l}V=\text { very high } \\
\left(1000 \mathrm{~s}^{-1}\right)\end{array}$ & $\begin{array}{l}V=\text { very high } \\
(10 \mathrm{ppm})\end{array}$ \\
\hline Example & LHOV: & \multicolumn{3}{|c|}{$\begin{array}{l}\text { low water mixing ratio, high photon flux, no external } \mathrm{OH} \text { reactivity (excluding } \mathrm{ON} \text { ), very high } \\
\text { initial NO mixing ratio }\end{array}$} \\
\hline & ML: & \multicolumn{3}{|c|}{ medium water mixing ratio, low photon flux } \\
\hline
\end{tabular}

Table 3. Definition of condition types in this study (good/risky/bad high-/low-NO conditions).

\begin{tabular}{|c|c|c|c|}
\hline Condition & Good & Risky & Bad \\
\hline Criterion & $\begin{array}{l}\mathrm{F} 185_{\exp } / \mathrm{OH}_{\exp }<3 \times 10^{3} \mathrm{~cm} \mathrm{~s}^{-1} \text { and } \\
\mathrm{F} 254_{\exp } / \mathrm{OH}_{\exp }<4 \times 10^{5} \mathrm{~cm} \mathrm{~s}^{-1}\end{array}$ & $\begin{array}{l}\mathrm{F} 185_{\exp } / \mathrm{OH}_{\exp }<1 \times 10^{5} \mathrm{~cm} \mathrm{~s}^{-1} \text { and } \\
\text { F254 exp } / \mathrm{OH}_{\exp }<1 \times 10^{7} \mathrm{~cm} \mathrm{~s}^{-1} \\
\text { (excluding good conditions) }\end{array}$ & $\begin{array}{l}\mathrm{F} 185_{\exp } / \mathrm{OH}_{\exp } \geq 1 \times 10^{5} \mathrm{~cm} \mathrm{~s}^{-1} \text { or } \\
\mathrm{F} 254_{\exp } / \mathrm{OH}_{\exp } \geq 1 \times 10^{7} \mathrm{~cm} \mathrm{~s}^{-1}\end{array}$ \\
\hline Condition & High NO & Low NO & \\
\hline Criterion* & $\frac{r\left(\mathrm{RO}_{2}+\mathrm{NO}\right)}{r\left(\mathrm{RO}_{2}+\mathrm{HO}_{2}\right)}>1$ & $\frac{r\left(\mathrm{RO}_{2}+\mathrm{NO}\right)}{r\left(\mathrm{RO}_{2}+\mathrm{HO}_{2}\right)} \leq 1$ & \\
\hline
\end{tabular}

* See Sect. S1 for details.

$\mathrm{F} 254_{\exp } / \mathrm{OH}_{\exp }<1 \times 10^{7} \mathrm{~cm} \mathrm{~s}^{-1}$ (excluding good conditions) to define "risky" conditions. Conditions with higher $\mathrm{F} 185_{\exp } / \mathrm{OH}_{\text {exp }}$ or $\mathrm{F} 254_{\exp } / \mathrm{OH}_{\exp }$ are defined as "bad". Under good conditions, the photolysis of most VOCs has a relative contribution $<20 \%$ to their fate; under bad conditions, non-tropospheric photolysis is likely to be significant in all OFR experiments since it can hardly be avoided for oxidation intermediates, even if the precursor(s) does not photolyze at all. Under risky conditions, some species photolyzing slowly and/or reacting with $\mathrm{OH}$ rapidly (e.g., alkanes, aldehydes, and most biogenics) still have a relative photolysis contribution of $<20 \%$ to their fates, while species photolyzing more rapidly and/or reacting with $\mathrm{OH}$ more slowly (e.g., aromatics and other highly conjugated species and some saturated carbonyls) will undergo substantial non-tropospheric photolysis. Note that these definitions are slightly different than in Peng et al. (2016). All definitions of the types of conditions are summarized in Table 3.

\subsection{Uncertainty analysis}

We apply the same method as in Peng et al. $(2014,2015)$ to calculate and analyze the output uncertainties due to uncertain kinetic parameters in the model. Random samples following lognormal distributions are generated for all rate constants and photoabsorption cross sections in the model using uncertainty data available in the JPL database (Sander et al., 2011) or estimated based on IUPAC data (Ammann et al., 2016). Then, Monte Carlo uncertainty propagation (BIPM et al., 2008) is performed for these samples through the model to obtain the distributions of outputs. Finally, we compute squared correlation coefficients between corresponding input and output samples and apportion the relative contributions of individual kinetic parameters to the output uncertainties based on these coefficients (Saltelli et al., 2005). 


\section{Results and discussion}

In this section, we study the $\mathrm{NO}_{y}$ chemistry in an OFR while considering relevant experimental issues. Based on these results, we propose some guidelines for OFR operation for high-NO OH oxidation of VOCs.

\section{1 $\mathrm{NO}_{y}$ chemistry in typical OFR cases with initial NO injection}

NO was thought to be unimportant (i.e., unable to significantly react with $\mathrm{RO}_{2}$ ) in OFRs with initial NO injection (OFR-iNO) based on the argument that its lifetime is too short due to large amounts of $\mathrm{O}_{3} \mathrm{OH}$, and $\mathrm{HO}_{2}$ to compete with $\mathrm{RO}_{2}+\mathrm{HO}_{2}$ (Li et al., 2015). We evaluate this issue below by calculating $\mathrm{NO}$ effective lifetime $\left(\tau_{\mathrm{NO}}\right.$; in $\left.\mathrm{s}\right)$, defined as $\mathrm{NO}$ exposure $\left(\mathrm{NO}_{\text {exp }}\right.$, in molecules $\mathrm{cm}^{-3} \mathrm{~s}$ ) divided by initial NO concentration, under various conditions. This definition cannot effectively capture the true NO average lifetime if it is close to or longer than the residence time. In this case, $\tau_{\mathrm{NO}}$ close to the residence time will be obtained, which is still long enough for our characterization purposes.

\subsubsection{OFR185-iNO}

In OFR185-iNO, NO is not oxidized extremely quickly under all conditions. For instance, under a typical condition in the midrange of the phase space shown in Fig. 1a, $\tau_{\mathrm{NO}} \sim 13 \mathrm{~s}$. This lifetime is much shorter than the residence time but long enough for $\mathrm{OH}_{\text {exp }}$ to reach $\sim 3 \times 10^{10}$ molecules $\mathrm{cm}^{-3} \mathrm{~s}$, which is equivalent to an $\mathrm{OH}$ equivalent age of $\sim 6 \mathrm{~h}$. Such an $\mathrm{OH}$ equivalent age is already sufficient to allow some VOC processing and even SOA formation to occur (Lambe et al., 2011; Ortega et al., 2016). Within $\tau_{\mathrm{NO}}$, NO suppresses $\mathrm{HO}_{2}$ through the reaction $\mathrm{NO}+\mathrm{HO}_{2} \rightarrow \mathrm{NO}_{2}+\mathrm{OH}$, leading to $\mathrm{NO}_{\exp } / \mathrm{HO}_{2 \exp }$ of $\sim 700$ during this period, which is high enough for $\mathrm{RO}_{2}$ to dominantly react with NO. Meanwhile, $\mathrm{NO}+\mathrm{HO}_{2} \rightarrow \mathrm{NO}_{2}+\mathrm{OH}$ enhances $\mathrm{OH}$ production, which helps $\mathrm{OH}_{\text {exp }}$ build up in a relatively short period. In addition, non-tropospheric photolysis of VOCs at 185 and $254 \mathrm{~nm}$ is minor (F185 exp $/ \mathrm{OH}_{\exp } \sim 600 \mathrm{~cm} \mathrm{~s}^{-1}$, Fig. 1a) because of enhanced $\mathrm{OH}$ production and moderate UV. Therefore, such an OFR condition may be of some interest for high-NO VOC oxidation. We thus analyze the $\mathrm{NO}_{y}$ chemistry in OFR185iNO in more detail below by taking the case shown in Fig. 1a as a representative example.

In OFR185-iNO, $\mathrm{HO}_{x}$ concentrations are orders of magnitude higher than in the atmosphere, while the amount of $\mathrm{O}_{3}$ produced is relatively small during the first several seconds after the flow enters the reactor. As a result, $\mathrm{NO}$ is not oxidized almost exclusively by $\mathrm{O}_{3}$ as in the troposphere, but also by $\mathrm{OH}$ and $\mathrm{HO}_{2}$ to form $\mathrm{HONO}$ and $\mathrm{NO}_{2}$, respectively (Fig. 1a). The large concentration of $\mathrm{OH}$ present then oxidizes $\mathrm{HONO}$ to $\mathrm{NO}_{2}$ and $\mathrm{NO}_{2}$ to $\mathrm{HNO}_{3}$. Photolysis only plays a negligible role in the fate of $\mathrm{HONO}$ and $\mathrm{NO}_{2}$ in OFRs in contrast to the troposphere where it is the main fate of these species. This is because the reactions of HONO and $\mathrm{NO}_{2}$ with $\mathrm{OH}$ are greatly accelerated in OFR compared to those in the troposphere, while photolysis not (Peng et al., 2016). The interconversion between $\mathrm{NO}_{2}$ and $\mathrm{HO}_{2} \mathrm{NO}_{2}$ is also greatly accelerated (Fig. 1a) since a large amount of $\mathrm{HO}_{2}$ promotes the formation of $\mathrm{HO}_{2} \mathrm{NO}_{2}$, the reaction with $\mathrm{OH}$ and thermal decomposition of which in turn enhance the recycling of $\mathrm{NO}_{2}$. Though not explicitly modeled in this study, $\mathrm{RO}_{2}$ is expected to undergo similar reactions with $\mathrm{NO}_{2}$ to form reservoir species, i.e., peroxynitrates (Orlando and Tyndall, 2012). Peroxynitrates that decompose on timescales considerably longer than OFR residence times may serve as effectively permanent $\mathrm{NO}_{y}$ sinks in OFRs (see Sect. 3.4.1).

Interestingly but not surprisingly, the $\mathrm{NO}_{y}$ chemistry shown in Fig. 1a is far from temporally uniform during the OFR residence time (Fig. S1a in the Supplement). Within $\tau_{\mathrm{NO}}, \mathrm{NO}$ undergoes an e-fold decay as it is rapidly converted into $\mathrm{NO}_{2}$ and $\mathrm{HONO}$ with concentrations that reach maxima around that time. After most $\mathrm{NO}$ is consumed, HONO and $\mathrm{NO}_{2}$ also start to decrease, but significantly more slowly than NO, since they do not have as many or efficient loss pathways as NO. The reaction of $\mathrm{OH}$ with $\mathrm{HONO}$, the dominant fate of HONO, is slower than that with NO (Fig. 1a). The net rate of the $\mathrm{NO}_{2}$-to- $\mathrm{HO}_{2} \mathrm{NO}_{2}$ conversion becomes low because of the relatively fast reverse reaction (Fig. 1a). The total loss of $\mathrm{NO}_{2}$ is also partially offset by the production from HONO. The generally stable concentrations of HONO and $\mathrm{NO}_{2}$ (Fig. S1a) result in their respective reaction rates with $\mathrm{OH}$ that are comparable during and after $\tau_{\mathrm{NO}}$ (Fig. 1a), as $\mathrm{OH}$ variation is also relatively small during the entire residence time (Fig. S1b). However, the $\mathrm{NO}_{2}$-to- $\mathrm{HO}_{2} \mathrm{NO}_{2}$ conversion after $\tau_{\mathrm{NO}}$ is much faster than during it (Fig. 1a) as a result of substantially decreased $\mathrm{NO}$ and $\mathrm{HO}_{2}$ concomitantly increasing by $>1$ order of magnitude after $\tau_{\mathrm{NO}}$ (Fig. S1a and b). $\mathrm{HNO}_{3}$ and $\mathrm{HO}_{2} \mathrm{NO}_{2}$, which are substantially produced only after $\mathrm{NO}_{2}$ is built up, have much higher concentrations later than within $\tau_{\mathrm{NO}}$.

Under other OFR185-iNO conditions than in Fig. 1a, the major reactions interconverting $\mathrm{NO}_{y}$ species are generally the same, although their relative importance may vary. At lower $\mathrm{NO}^{\text {in }}$, the perturbation of $\mathrm{HO}_{x}$ chemistry caused by $\mathrm{NO}_{y}$ species is smaller. The effects of $\mathrm{NO}^{\text {in }}$ less than $1 \mathrm{ppb}$ (e.g., typical non-urban ambient concentrations) are generally negligible regarding $\mathrm{HO}_{x}$ chemistry. Regarding $\mathrm{NO}_{y}$ species, the pathways in Fig. 1a are still important under those conditions. At higher $\mathrm{NO}^{\text {in }}$ (e.g., $>1 \mathrm{ppm}$ ), one might expect $\mathrm{NO}_{3}$ and $\mathrm{N}_{2} \mathrm{O}_{5}$ to play a role (as in OFR254-iNO; see Sect. 3.1.2 below) since high $\mathrm{NO}_{y}$ concentrations might enhance self- or cross- reactions of $\mathrm{NO}_{y}$. However, this would not occur unless $\mathrm{OH}$ production is high since relatively low $\mathrm{O}_{3}$ concentrations in OFR185-iNO cannot oxidize $\mathrm{NO}_{2}$ to $\mathrm{NO}_{3}$ rapidly. Also, a large amount of $\mathrm{NO}_{y}$ can lead to significant $\mathrm{OH}$ suppression. That would in turn slow down the $\mathrm{NO}_{3}$ production from $\mathrm{HNO}_{3}$ by $\mathrm{OH}$. This is especially true 


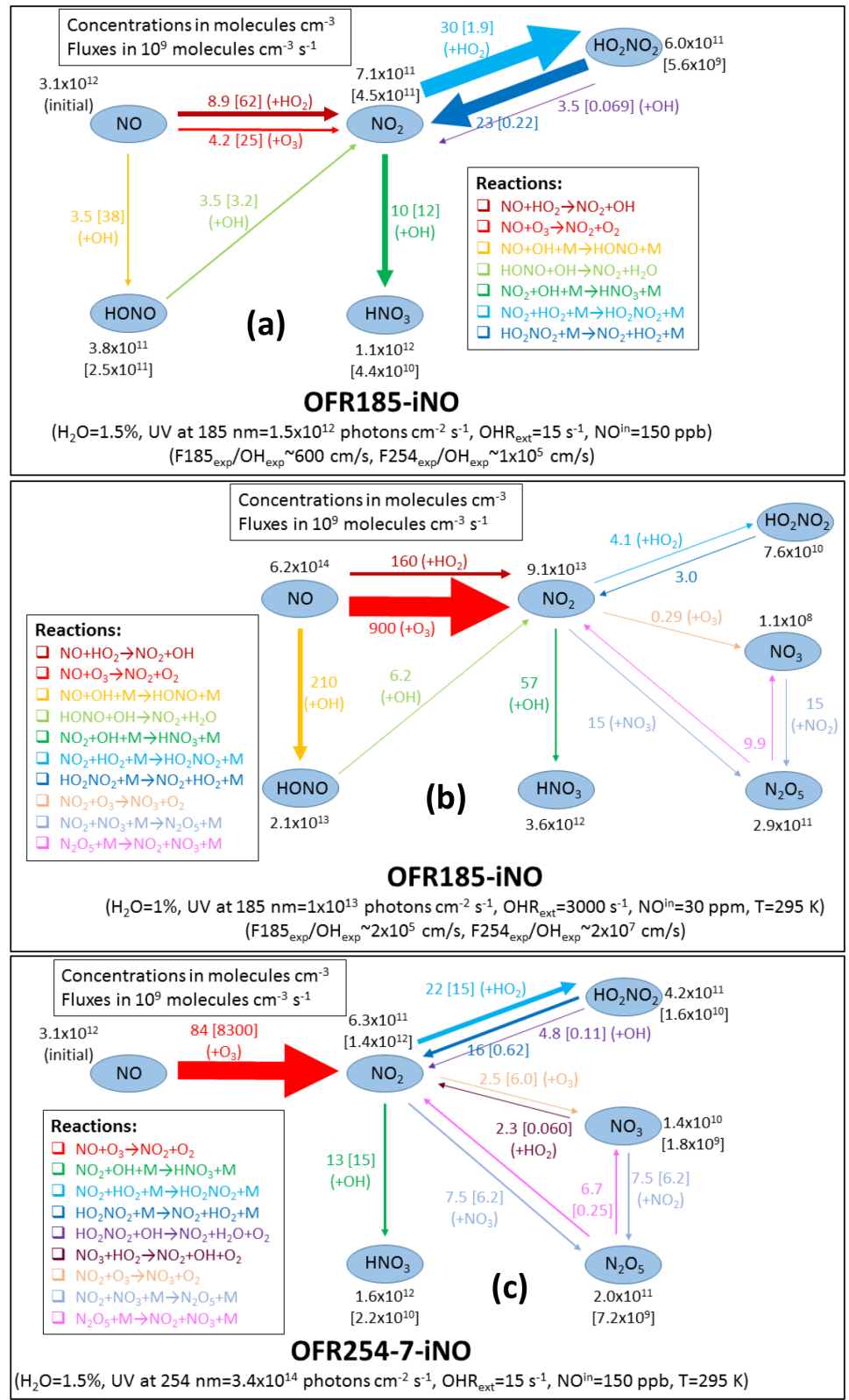

Figure 1. Schematics of main N-containing species and their major interconversion pathways under typical input conditions for (a) OFR185iNO with $\mathrm{NO}^{\text {in }}=150 \mathrm{ppb}$, (b) OFR254-7-iNO with $\mathrm{NO}^{\text {in }}=150 \mathrm{ppb}$, and (c) OFR185-iNO with NO ${ }^{\text {in }}=30$ ppm. Species average concentrations (in molecules $\mathrm{cm}^{-3}$ ) are shown in black beside species names. Arrows denote directions of the conversions. Average reaction fluxes (in units of $10^{9}$ molecules $\mathrm{cm}^{-3} \mathrm{~s}^{-1}$ ) are calculated according to the production rate and shown on or beside the corresponding arrows and in the same color. Within each schematic, the thickness of the arrows is a measure of their corresponding species flux. Multiple arrows in the same color and pointing to the same species should be counted only once for reaction flux on a species. Note that all values in these schematics are average ones over the residence time, except for those in square brackets in panels (a) and (b), which are average values within approximate NO effective lifetime ( $\tau_{\mathrm{NO}}$, or more accurately, an integer multiple of the model's output time step closest to NO effective lifetime). All concentrations and fluxes have two significant digits.

when an OFR is used to oxidize the output of highly concentrated sources (e.g., from vehicle exhausts). When sources corresponding to $\mathrm{OHR}_{\text {ext }}$ of thousands of $\mathrm{s}^{-1}$ and $\mathrm{NO}^{\text {in }}$ of tens of ppm are injected into OFR185 (Fig. 1b), they essentially inhibit active chemistry except $\mathrm{NO}$ consumption, as all subsequent products are much less abundant compared to remaining NO (Fig. S1c). 


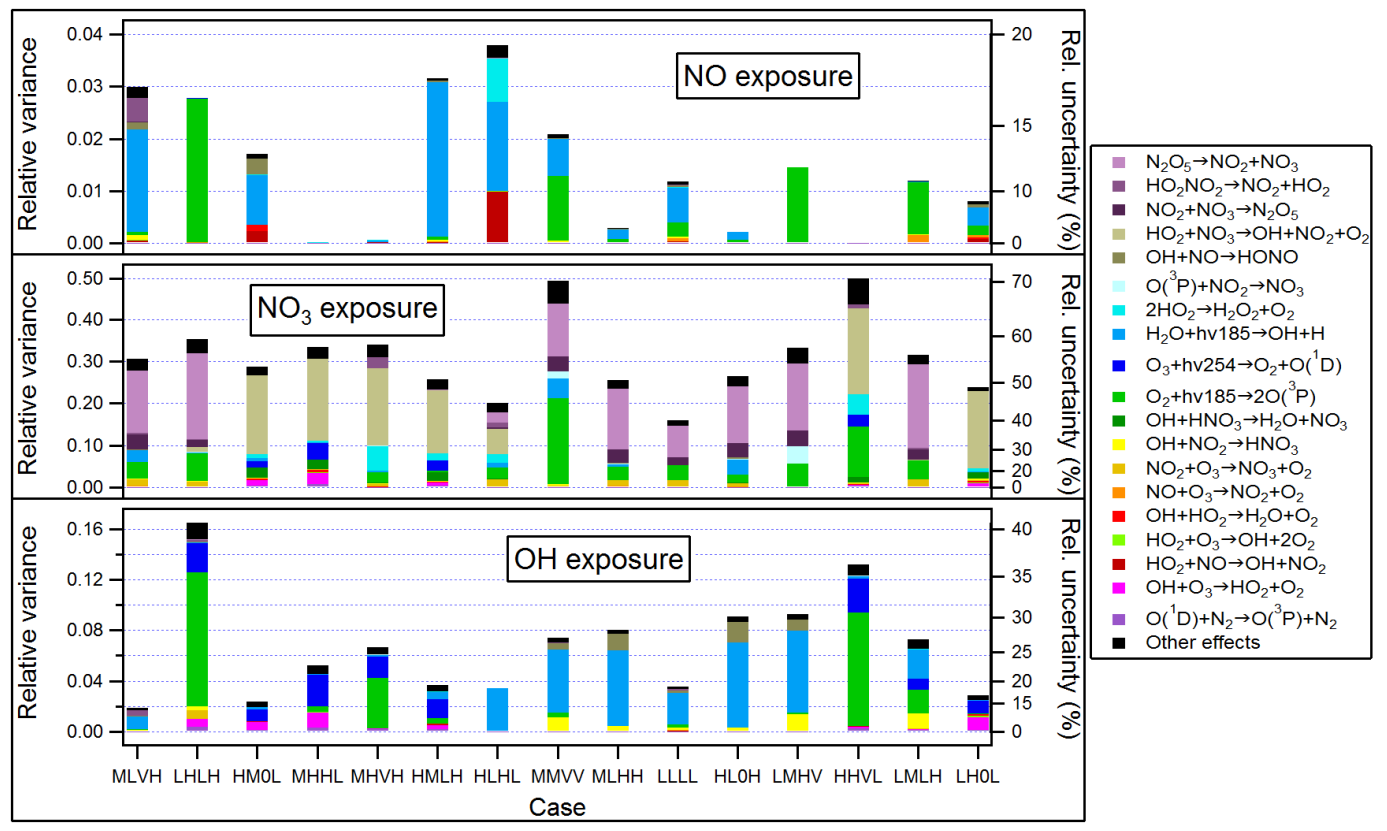

Figure 2. Relative variances (left axes) and uncertainties (right axes) in several outputs (i.e., $\mathrm{NO}, \mathrm{NO}_{3}$, and $\mathrm{OH}$ exposures) of Monte Carlo uncertainty propagation and relative contributions of key reactions to these relative variances in several typical cases (denoted in fourcharacter labels; see Table 2 for the typical case label code) in OFR185-iNO. Relative variances are shown in linear scales (left axis), while corresponding relative uncertainties equal to relative variances' square roots are indicated by the nonlinear right axis. Only the reactions with a contribution of no less than 0.04 to at least one relative variance are shown.

\subsubsection{OFR254-iNO}

The ppm level $\mathrm{O}_{3 \text {,in }}$ used in the OFR254-iNO mode of operation has a strong impact on its $\mathrm{NO}_{y}$ chemistry. $\mathrm{An}_{3}$,in of $2.2 \mathrm{ppm}$ (lowest in this study) is already enough to shorten $\tau_{\mathrm{NO}}$ to $\sim 1 \mathrm{~s}$, preventing NO from playing a role in the chemistry under most explored conditions. The reaction fluxes under a typical $\mathrm{O}_{3 \text {,in }}$ of $7 \mathrm{ppm}$ are shown in Fig. 1c. A reactive flux from $\mathrm{NO}+\mathrm{O}_{3} \rightarrow \mathrm{NO}_{2}$ makes the reaction of $\mathrm{NO}$ with other oxidants $\left(\mathrm{OH}, \mathrm{HO}_{2}\right.$, etc.) negligible. The $\mathrm{HNO}_{3}$ production pathway from $\mathrm{NO}_{2}$ is similar to that in OFR185-iNO. The interconversion between $\mathrm{NO}_{2}$ and $\mathrm{HO}_{2} \mathrm{NO}_{2}$ is also fast over the residence time and even faster than in OFR185-iNO during $\tau_{\mathrm{NO}}$ since a high concentration of $\mathrm{O}_{3}$ also controls the $\mathrm{OH}-\mathrm{HO}_{2}$ interconversion and makes $\mathrm{HO}_{2}$ more resilient against suppression due to high NO (Fig. S1f; Peng et al., 2015). A major difference in the $\mathrm{NO}_{y}$ chemistry in OFR254iNO (Fig. 1c) compared to OFR185-iNO (Fig. 1a) is significant $\mathrm{NO}_{3} / \mathrm{N}_{2} \mathrm{O}_{5}$ chemistry due to high $\mathrm{O}_{3}$ in OFR254-iNO, which accelerates the oxidation of $\mathrm{NO}_{2}$ to $\mathrm{NO}_{3}$. Interconversion between $\mathrm{NO}_{2}+\mathrm{NO}_{3}$ and $\mathrm{N}_{2} \mathrm{O}_{5}$ also occurs to a significant extent because of high $\mathrm{NO}_{2}$. Under the conditions of Fig. 1c, $\mathrm{NO}_{3}$ can also be significantly consumed by $\mathrm{HO}_{2}$. Unlike OFR185-iNO, OFR254-iNO can substantially form $\mathrm{NO}_{3}$ from $\mathrm{HNO}_{3}$ under conditions that are not on the extremes of the explored physical condition space, e.g., at higher UV and lower $\mathrm{NO}^{\text {in }}$ (e.g., Fig. S2). In the case of very high $\mathrm{NO}^{\text {in }}$ (equal to or higher than $\mathrm{O}_{3 \text {,in }}$ ), all $\mathrm{O}_{3}$ can be rapidly destroyed by NO. As a consequence, $\mathrm{OH}$ production is shut down and these cases are of little practical interest (Fig. S3h).

\subsubsection{Uncertainty analysis}

The results of uncertainty propagation confirm that the output uncertainties due to uncertain kinetic parameters are relatively low compared to other factors (e.g., non-plug flow in OFR; Peng et al., 2015) and the overall model accuracy compared to experimental data (a factor of 2-3; Li et al., 2015). For OFR185-iNO, $\mathrm{NO}, \mathrm{NO}_{3}$, and $\mathrm{OH}$ exposures have relative uncertainties of $\sim 0-20, \sim 40-70$, and $\sim 15-40 \%$, respectively. The uncertainties in $\mathrm{OH}$ exposure are very similar to those in the cases without $\mathrm{NO}_{x}$ (Peng et al., 2015). The contribution of $\mathrm{NO}_{y}$ reactions to $\mathrm{OH}_{\text {exp }}$ uncertainty is negligible, except for some contribution of $\mathrm{OH}+\mathrm{NO} \rightarrow \mathrm{HONO}$ in a few cases with high $\mathrm{NO}^{\text {in }}$ (Fig. 2). The uncertainties in $\mathrm{NO}_{\text {exp }}$ are dominated by the reactions producing $\mathrm{HO}_{x}$ and $\mathrm{O}_{3}$, i.e., the major consumers of $\mathrm{NO}$. For $\mathrm{NO}_{3}$ exposure, a few major production and loss pathways (e.g., $\mathrm{NO}_{2}+\mathrm{NO}_{3} \rightarrow \mathrm{N}_{2} \mathrm{O}_{5}$, $\mathrm{N}_{2} \mathrm{O}_{5} \rightarrow \mathrm{NO}_{2}+\mathrm{NO}_{3}$, and $\mathrm{HO}_{2}+\mathrm{NO}_{3} \rightarrow \mathrm{OH}+\mathrm{NO}_{2}+\mathrm{O}_{2}$ ) dominate its uncertainties. OFR254-iNO has a simpler picture of parametric uncertainties in terms of composition. $\mathrm{O}_{3}$ controls the $\mathrm{NO}$ oxidation under most conditions and this reaction contributes most of the output uncertainties for NO exposures. $\mathrm{HO}_{2}+\mathrm{NO}_{3} \rightarrow \mathrm{OH}+\mathrm{NO}_{2}+\mathrm{O}_{2}$ dominates the uncertainty in $\mathrm{NO}_{3}$ exposure. The levels of those uncertain- 
ties are lower than in OFR185-iNO $(<2 \%$ for NO exposure, $<60 \%$ in all cases, and $<25 \%$ in most cases for $\mathrm{NO}_{3}$ exposure). Thus, model uncertainties in OFR254-iNO are not shown in detail.

\subsection{Different conditions types}

Having illustrated the main $\mathrm{NO}_{y}$ chemical pathways for typical cases, we present the results of the exploration of the entire physical parameter space (see Sect. 2.2). Note that the explored space is indeed very large and gridded logarithmically uniformly in every dimension. Therefore, the statistics of the exploration results can be useful to determine the relative importance of the condition types defined in Sect. 2.2 and Table 3.

It has been shown that during $\tau_{\mathrm{NO}}, \mathrm{RO}_{2}$ can react dominantly with NO (Sect. 3.1.1), while the entire residence time is considered to determine if a condition is high-NO (see Table 3). This is done because for VOC oxidation systems of interest, there will be significant oxidation of the initial VOC and its products under low-NO conditions if $\tau_{\mathrm{NO}}$ is shorter than the reactor residence time. After most NO is consumed, the longer the remaining residence time, the more $\mathrm{RO}_{2}$ will react with $\mathrm{HO}_{2}$ and the more likely that an input condition is classified as low NO. For a condition to be high NO, a significantly long $\tau_{\mathrm{NO}}$ is required. Figure 3 shows the fractional occurrence distribution of good, risky, and bad conditions in the entire explored condition space over logarithm of $r\left(\mathrm{RO}_{2}+\mathrm{NO}\right) / r\left(\mathrm{RO}_{2}+\mathrm{HO}_{2}\right)$, which distinguishes high- and low-NO conditions. In OFR254-iNO, $\tau_{\mathrm{NO}}$ is so short that no good high-NO condition is found in the explored range in this study (Fig. 3a). A fraction of explored conditions are bad high-NO. These conditions result from a full consumption of $\mathrm{O}_{3}$ by NO. Then very little $\mathrm{HO}_{x}$ is produced (right panels in Fig. S3h), but the fate of any $\mathrm{RO}_{2}$ formed is dominated by $\mathrm{RO}_{2}+\mathrm{NO}$ (right panels in Fig. S3i). However, also due to negligibly low $\mathrm{OH}$ concentration, little $\mathrm{RO}_{2}$ is produced and non-tropospheric photolysis of VOCs is also substantial compared to their reaction with $\mathrm{OH}$ under these conditions, classifying all of them as "bad" (Fig. 3a).

In OFR185-iNO, in addition to the typical case shown in Fig. 1a, many other cases have a $\tau_{\mathrm{NO}}$ of $\sim 10 \mathrm{~s}$ or longer (Figs. S3b and S4), which allows for the possibility of highNO conditions. Indeed, $\sim 1 / 3$ of explored conditions in OFR185-iNO with a residence time of $3 \mathrm{~min}$ are high NO (Fig. 3b). Most of these high-NO conditions are also classified as bad, similar to those in OFR254-iNO. More importantly, in contrast to OFR254-iNO, good and risky highNO conditions also comprise an appreciable fraction of the OFR185-iNO conditions. It is easily expected that very high $\mathrm{OHR}_{\text {ext }}$ and $\mathrm{NO}^{\text {in }}$ lead to bad high-NO conditions (all panels in Fig. 4) since they strongly suppress $\mathrm{HO}_{x}$, which yields bad conditions and in turn keeps NO destruction relatively low. The occurrence of bad high-NO conditions is reduced at high UV (bottom panels in Fig. 4), which can be explained by

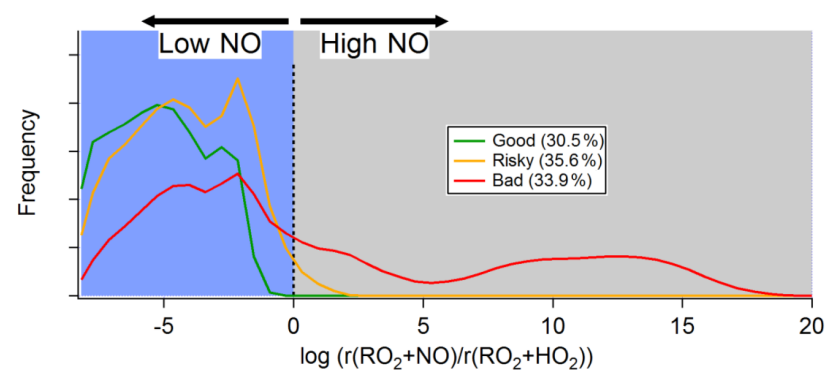

(a) OFR254-iNO

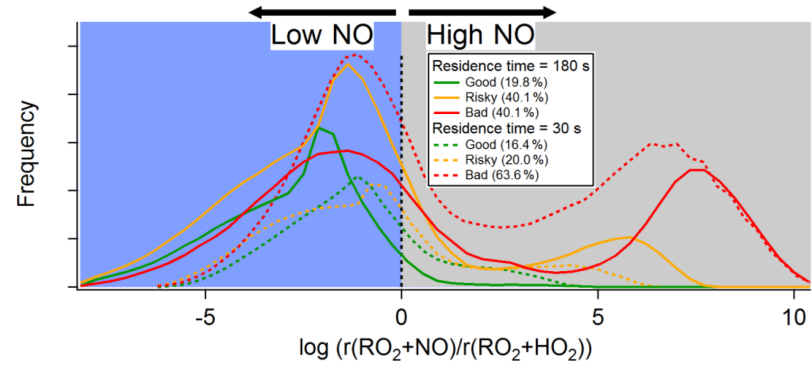

(b) OFR185-iNO

Figure 3. Frequency occurrence distributions of good, risky, and bad conditions (see Table 3) over logarithm of the ratio between $\mathrm{RO}_{2}$ reacted with $\mathrm{NO}$ and with $\mathrm{HO}_{2}$ (see Sect. S1 for more detail) for (a) OFR254-iNO (only the case with a residence time of $180 \mathrm{~s}$ ) and (b) OFR185-iNO (including two cases with residence times of 180 and 30 s). Low- and high-NO regions (see Table 3) are colored in light blue and gray, respectively.

lowered $\mathrm{NO}$ due to high $\mathrm{O}_{3}$ production and fast $\mathrm{OH}$ reactant loss due to high $\mathrm{OH}$ production. Good high-NO conditions are rare in the explored space. They are only $1.1 \%$ of total explored conditions (Fig. 3b) and present under very specific conditions, i.e., higher $\mathrm{H}_{2} \mathrm{O}$, lower UV, lower $\mathrm{OHR}_{\text {ext }}$, and $\mathrm{NO}^{\text {in }}$ of tens to hundreds of ppb (Figs. 4 and S5). Since a very high $\mathrm{NO}$ can suppress $\mathrm{OH}$, to obtain both a significant NO level and good conditions, $\mathrm{NO}^{\text {in }}$ can only be tens to hundreds of ppb. As $\mathrm{NO}^{\mathrm{in}}$ is lower and $\mathrm{OH}$ is higher than under bad high-NO conditions, UV should be lower than bad highNO conditions to keep a sufficiently long presence of NO. Thus, UV levels at $185 \mathrm{~nm}$ for good high-NO conditions are generally lower than $10^{12}$ photons $\mathrm{cm}^{-2} \mathrm{~s}^{-1}$ (Fig. S5). In addition, a low $\mathrm{OHR}_{\text {ext }}$ (generally $<50 \mathrm{~s}^{-1}$ ) and a higher $\mathrm{H}_{2} \mathrm{O}$ (the higher the better, although there is no apparent threshold) are also required for good high-NO conditions (Fig. S5), as Peng et al. (2016) pointed out. Risky high-NO conditions often occur between good and bad high-NO conditions, e.g., at lower $\mathrm{NO}^{\text {in }}$ than bad conditions (e.g., Cases ML, MM, HL, and $\mathrm{HM}$ in Fig. 4; see Table 2 for the typical case label code), at higher $\mathrm{OHR}_{\text {ext }}$ and/or $\mathrm{NO}_{\text {in }}$ than good conditions (e.g., Cases ML and MM), and at lower $\mathrm{H}_{2} \mathrm{O}$ than good conditions (e.g., Case LL). 

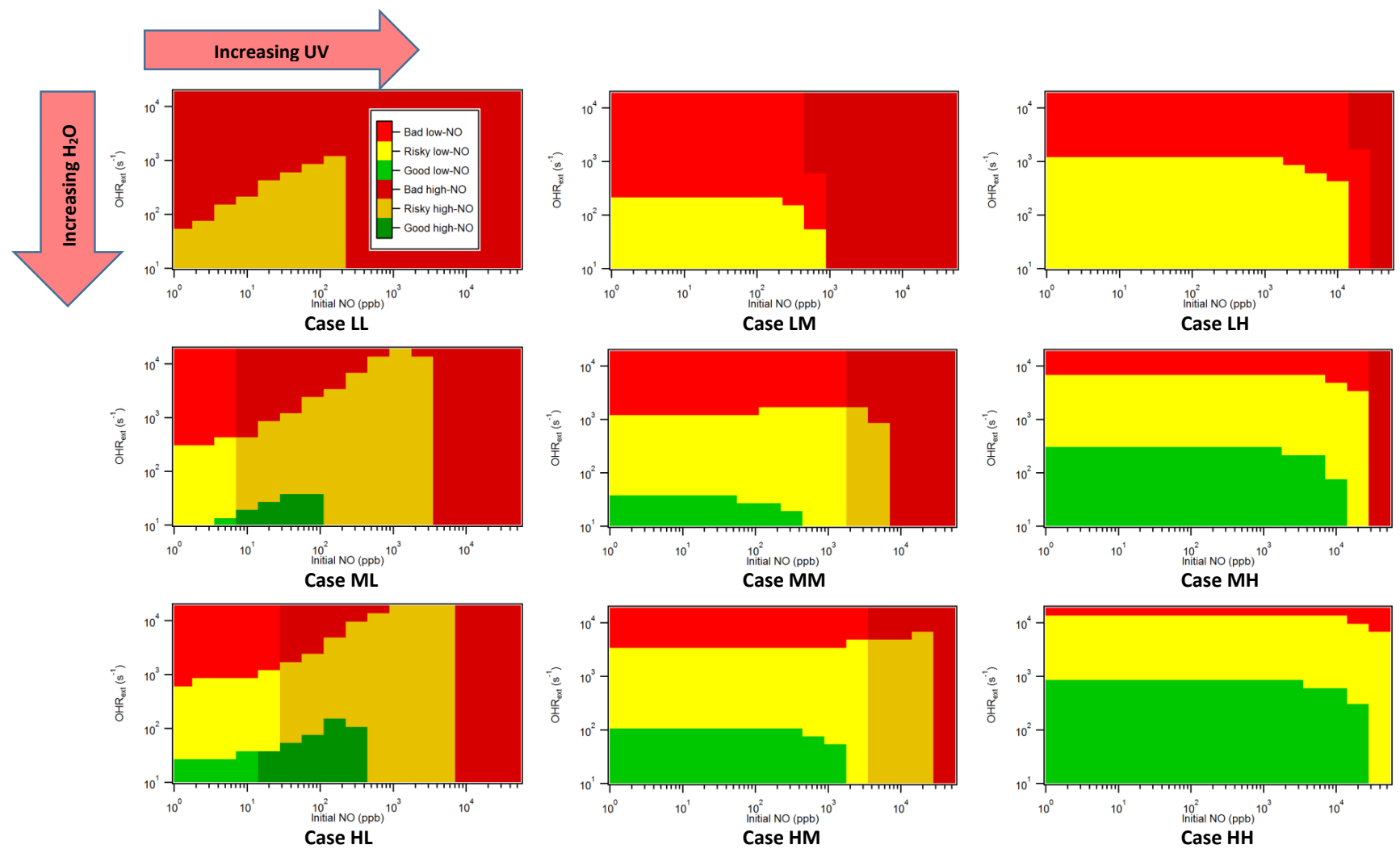

Figure 4. Image plots of the condition types defined in Table 3 vs. external OH reactivity (excluding N-containing species) and initial NO for several typical cases in OFR185-iNO (see Table 2 for the case label code).

The trend in the distributions of good, risky, and bad low-NO conditions is generally in line with the analysis in Peng et al. (2016). For low-NO conditions, $\mathrm{NO}_{y}$ species can be simply regarded as external $\mathrm{OH}$ reactants, as in Peng et al. (2016). As $\mathrm{H}_{2} \mathrm{O}$ decreases and/or $\mathrm{OHR}_{\text {ext }}$ or $\mathrm{NO}^{\text {in }}$ increases, a low-NO condition becomes worse (good $\rightarrow$ risky $\rightarrow$ bad; Figs. 4 and 5). In OFR185-iNO, increasing UV generally makes a low-NO condition better because of an $\mathrm{OH}$ production enhancement (Fig. 4), while in OFR254-iNO, increasing UV generally makes a low-NO condition worse (Fig. 5) since at a higher $\mathrm{UV}$ more $\mathrm{O}_{3}$ is destroyed and the resilience of $\mathrm{OH}$ to suppression is reduced.

As discussed above, the fraction of high-NO conditions also depends on OFR residence time. A shorter residence time is expected to generally lead to a larger fraction of high-NO conditions since the time spent in the reaction for $t>\tau_{\mathrm{NO}}$ is significantly smaller. Thus, we also investigate an OFR185-iNO case with a residence time of $30 \mathrm{~s}$. In Fig. 3b, compared to the case with a residence time of 3 min, the distributions of all condition types (good, risky, and bad) of the $30 \mathrm{~s}$ residence time case shift toward higher $r\left(\mathrm{RO}_{2}+\mathrm{NO}\right) / r\left(\mathrm{RO}_{2}+\mathrm{HO}_{2}\right)$. Nevertheless, shortening the residence time also removes the period when the condition is better (i.e., less non-tropospheric photolysis), when external $\mathrm{OH}$ reactants have been partially consumed, and
$\mathrm{OH}$ suppression due to $\mathrm{OHR}_{\text {ext }}$ has been reduced later in the residence time. As a result, the fractions of good and risky conditions decrease (Fig. 3b). With the two effects (higher $r\left(\mathrm{RO}_{2}+\mathrm{NO}\right) / r\left(\mathrm{RO}_{2}+\mathrm{HO}_{2}\right)$ and more significant non-tropospheric photolysis) combined, the fraction of good high-NO conditions increases by a factor of $\sim 3$. An even shorter residence time does not result in a larger good highNO fraction since the effect of enhancing non-tropospheric photolysis is even more apparent.

\subsection{Effect of non-plug flow}

We performed model runs in which the only change with respect to our box model introduced in Sect. 2.2 is that the plug flow assumption is replaced by the residence time distribution (RTD) measured by Lambe et al. (2011; see also Fig. S8 of Peng et al., 2015). The chemistry of different air parcels with different residence times is simulated by our box model and outputs are averaged over the RTD. Lateral diffusion between different air parcels is neglected in these simulations.

$\mathrm{OH}_{\text {exp }}$ calculated from the mode with RTD $\left(\mathrm{OH}_{\text {exp,RTD }}\right)$ is higher than that calculated from the plug flow model $\left(\mathrm{OH}_{\text {exp,PF}}\right)$ in both OFR185-iNO and OFR254-iNO (Table 4 and Fig. S6). Under most explored conditions deviations are relatively small, which leads to an overall posi- 

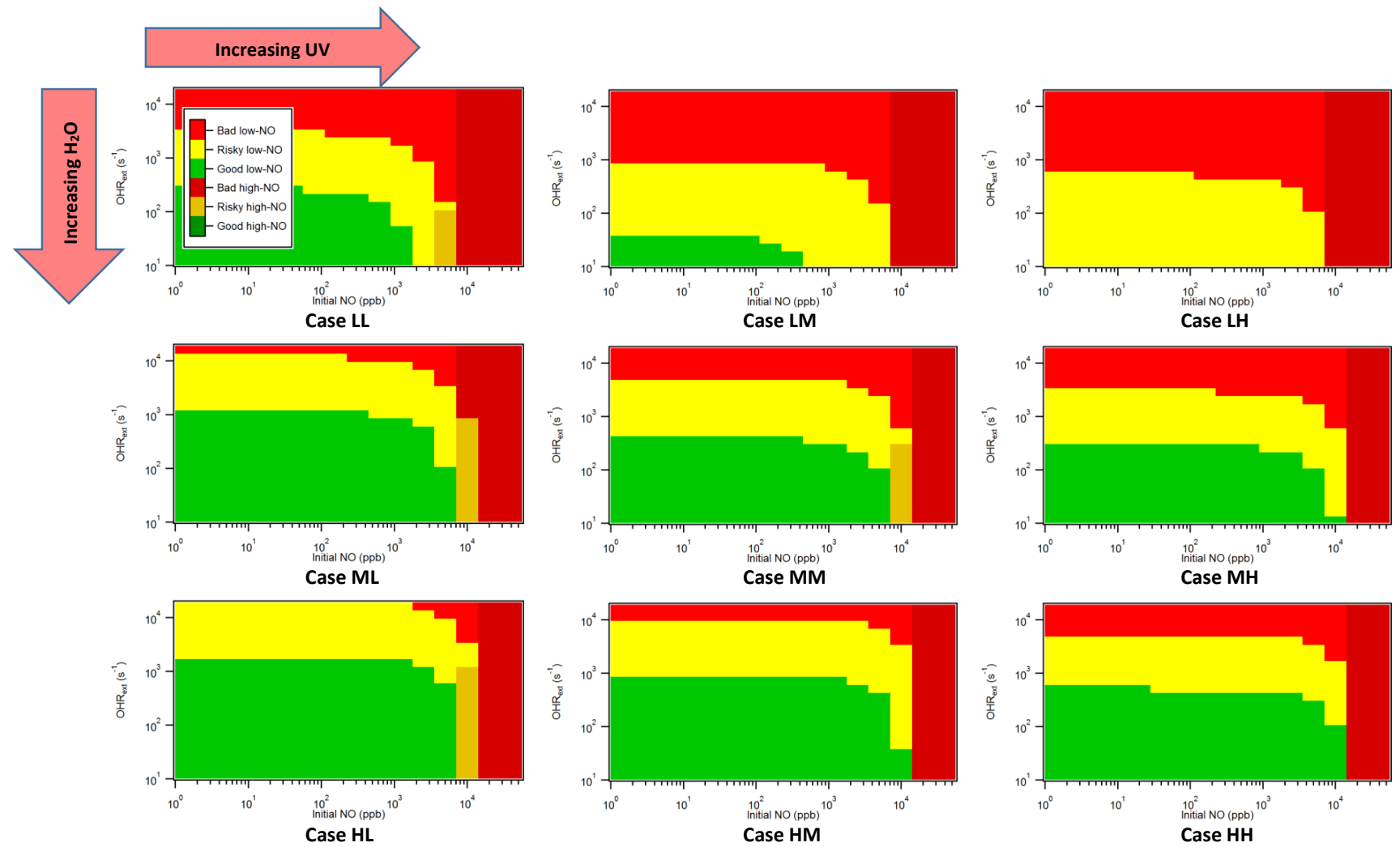

Figure 5. Same format as Fig. 4 but for OFR254-22-iNO.

tive deviation of $\mathrm{OH}_{\text {exp, RTD }}$ from $\mathrm{OH}_{\text {exp,PF }}$ by $\sim \times 2$ (within the uncertainties of the model and its application to real experimental systems). For OFR185-iNO, most conditions $(\sim 90 \%)$ in the explored space lead to $<\times 3$ differences between $\mathrm{OH}_{\text {exp,PF }}$ and $\mathrm{OH}_{\text {exp, RTD }}$, while for a small fraction of cases the differences can be larger (Fig. S6). The larger deviations are mainly present at high $\mathrm{UV}, \mathrm{OHR}_{\text {ext }}$, and $\mathrm{NO}^{\text {in }}$ in which conditions are generally bad and in which experiments are of little atmospheric relevance. Under these specific conditions, external $\mathrm{OH}$ reactants and $\mathrm{NO}_{y}$ can be substantially destroyed for the air parcels with residence times longer than the average, while this is not the case for the average residence time. This feature was already described by Peng et al. (2015; see Fig. S10 of that study). Although only non$\mathrm{NO}_{y}$ external $\mathrm{OH}$ reactants were considered in that study, the results are the same. In the present study, a higher upper limit

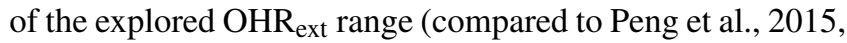
due to trying to simulate the extremely high $\mathrm{OHR}_{\text {ext }}$ used in some recent literature studies) leads to large amounts of $\mathrm{NO}_{y}$ and causes somewhat larger deviations. In OFR254-iNO, OH is less suppressed at high $\mathrm{OHR}_{\mathrm{ext}}$ and $\mathrm{NO}^{\text {in }}$ than in OFR185iNO because of high $\mathrm{O}_{3}$ (Peng et al., 2015); $\mathrm{OH}_{\text {exp, RTD devi- }}$ ations from $\mathrm{OH}_{\text {exp,PF }}$ are also smaller (Table 4).

Based on the outputs of the model with RTD, a similar mapping of the physical input space as in Figs. 4 and 5 can be done (Figs. S7 and S8). Overall, the mapping of
Table 4. Statistics of the ratio between $\mathrm{OH}$ exposures calculated in the model with the Lambe et al. (2011) residence time distribution $\left(\mathrm{OH}_{\text {exp, RTD }}\right)$ and in the plug flow model $\left(\mathrm{OH}_{\text {exp, } \mathrm{PF}}\right)$. The geometric mean, uncertainty factor (geometric standard deviation), and percentage of outlier cases $(>3$ or $<1 / 3)$ are shown for OFR185iNO, OFR254-70-iNO, and OFR254-7-iNO.

\begin{tabular}{lccr}
\hline & $\begin{array}{c}\text { Geometric } \\
\text { mean }\end{array}$ & $\begin{array}{c}\text { Uncertainty } \\
\text { factor }\end{array}$ & $\begin{array}{r}\text { Outlier } \\
\text { cases } \\
(\%)\end{array}$ \\
\hline OFR185-iNO & 1.91 & 1.64 & 11 \\
OFR254-7-iNO & 1.59 & 1.51 & 7 \\
OFR254-70-iNO & 1.48 & 1.29 & 3 \\
\hline
\end{tabular}

the RTD model results is very similar to that of the plug flow model. The conditions appear to be only slightly better in a few places of the explored space than those from the plug flow model, which can be easily explained by the discussions above. The mapping in Figs. S7 and S8 also appear to be slightly more low NO for the same reasons discussed above. After NO is destroyed at long residence times, $\mathrm{HO}_{2}$ suppressed by $\mathrm{NO}$ also recovers as $\mathrm{OH}$, and $r\left(\mathrm{RO}_{2}+\mathrm{NO}\right) / \mathrm{r}\left(\mathrm{RO}_{2}+\mathrm{HO}_{2}\right)$ is clearly expected to be smaller than in the plug flow model in general. 
Note that most conditions that appear to be better in the RTD model results are already identified as bad by the plug flow model. Those conditions look slightly better only because of their better RTD-averaged $\mathrm{F} 185_{\exp } / \mathrm{OH}_{\exp }$ and $\mathrm{F} 254_{\exp } / \mathrm{OH}_{\text {exp }}$. However, each of those cases is actually composed of both a better part at longer residence times and also a worse part at shorter residence times. Under those conditions, the reactor simultaneously works in two distinct regimes, one of which is bad due to heavy $\mathrm{OH}$ suppression. Such conditions are clearly not desirable for OFR operation.

\subsection{Possible issues related to high $\mathrm{NO}_{x}$ levels}

In the discussion above, we focused on obtaining high-NO conditions and considered only one experimental issue (nontropospheric photolysis) that had been previously investigated in Peng et al. (2016) and is not specific for experiments with high NO injection. We discuss additional potential reasons why the OFR-iNO chemistry can deviate strongly from tropospheric conditions as specifically related to high $\mathrm{NO}_{x}$ levels in this subsection.

\subsection{1 $\mathrm{NO}_{2}$}

$\mathrm{NO}_{2}$ reacts with $\mathrm{RO}_{2}$ to form peroxynitrates, which are generally regarded as reservoir species in the atmosphere as most of them thermally decompose very quickly compared to atmospheric timescales. However, in OFRs with residence times on the order of minutes, some peroxynitrates may no longer be considered as fast decomposing. This is especially true for acylperoxy nitrates with lifetimes that can be hours at room temperature (Orlando and Tyndall, 2012). Acylperoxy nitrates are essentially sinks instead of reservoirs in OFRs for both $\mathrm{NO}_{2}$ and $\mathrm{RO}_{2} \cdot \mathrm{RO}_{2}$ is estimated to be as high as several ppb in OFRs by our model (e.g., $\sim 6 \mathrm{ppb} \mathrm{RO}_{2}$ in OFR185 at $\mathrm{H}_{2} \mathrm{O}=1 \%$, UV at $185 \mathrm{~nm}=1 \times 10^{13}$ photons $\mathrm{cm}^{-2} \mathrm{~s}^{-1}, \mathrm{OHR}_{\mathrm{ext}}=1000 \mathrm{~s}^{-1}$, and $\mathrm{NO}^{\text {in }}=0$ ), while high-NO experiments can yield far higher $\mathrm{NO}_{2}$. If all $\mathrm{RO}_{2}$ were acylperoxy, the $\mathrm{RO}_{2}$ chemistry could be rapidly shut down by $\mathrm{NO}_{2}$, as rate constants of these $\mathrm{RO}_{2}+\mathrm{NO}_{2}$ reactions are around $10^{-11} \mathrm{~cm}^{3}$ molecule ${ }^{-1} \mathrm{~s}^{-1}$ (Orlando and Tyndall, 2012). Nevertheless, acyl peroxynitrates are not expected to typically be the dominant component of peroxynitrates since acyl radicals are not a direct oxidation product of most common VOCs and can only be formed after several steps of oxidation (Atkinson and Arey, 2003; Ziemann and Atkinson, 2012). Most alkylperoxy nitrates retain their short-lived reservoir characteristics in OFRs due to their relatively short thermal decomposition timescales (on the order of $0.1 \mathrm{~s}$; Orlando and Tyndall, 2012). Even so, OFR experiments can be seriously hampered at extremely high $\mathrm{NO}_{2}$. If $\mathrm{NO}_{2}$ reaches ppm levels, the equilibrium between $\mathrm{RO}_{2}+\mathrm{NO}_{2}$ and alkylperoxy nitrate $\left(\mathrm{RO}_{2}+\mathrm{NO}_{2} \leftrightarrow \mathrm{RO}_{2} \mathrm{NO}_{2}\right)$ is greatly shifted toward the alkylperoxy nitrate side, as the forward and reverse rate con- stants are on the order of $10^{-12} \mathrm{~cm}^{3}$ molecule ${ }^{-1} \mathrm{~s}^{-1}$ and $1 \mathrm{~s}^{-1}$, respectively (Orlando and Tyndall, 2012). This results in a substantial decrease in effective $\mathrm{RO}_{2}$ concentration, or in other words, a substantial slowdown of $\mathrm{RO}_{2}$ chemistry.

Parts per million levels of $\mathrm{NO}_{2}$ may impose an additional experimental artifact in the oxidation chemistry of aromatic precursors. $\mathrm{OH}$-aromatic adducts, i.e., the immediate products of aromatic oxidation by $\mathrm{OH}$, undergo the addition of $\mathrm{O}_{2}$ and $\mathrm{NO}_{2}$ at comparable rates under ppm levels of $\mathrm{NO}_{2}$ (rate constants of the additions of $\mathrm{O}_{2}$ and $\mathrm{NO}_{2}$ are on the order of $10^{-16}$ and $10^{-11}$ molecules $\mathrm{cm}^{-3} \mathrm{~s}^{-1}$, respectively; Atkinson and Arey, 2003). However, only the former addition is atmospherically relevant (Calvert et al., 2002). Liu et al. (2015) performed OFR254-iNO experiments with toluene over a range of $\mathrm{NO}^{\text {in }}$ of $2.5-10 \mathrm{ppm}$, encompassing the $\mathrm{NO}$ concentration range at which the reactions of $\mathrm{OH}-$ toluene adduct with $\mathrm{O}_{2}$ and with $\mathrm{NO}_{2}$ are of equal importance $(\sim 5 \mathrm{ppm}$; Atkinson and Arey, 2003). This suggests that nitroaromatics, the formation of which was reported in the study of Liu et al. (2015), might have been formed in substantial amounts in that study through the addition of $\mathrm{NO}_{2}$ to the $\mathrm{OH}$-toluene adduct.

\subsection{2 $\mathrm{NO}_{3}$}

As discussed in Sect. 3.1, $\mathrm{NO}_{3}$ can be formed in significant amounts in OFRs with high $\mathrm{NO}$ injection. Although $\mathrm{NO}_{3}$ is also present in the atmosphere, especially during nighttime, significant VOC oxidation by both $\mathrm{OH}$ and $\mathrm{NO}_{3}$ results in more complex chemistry that may complicate the interpretation of experimental results. $\mathrm{NO}_{3}$ oxidation-only OFRs have been previously realized experimentally via the thermal dissociation of injected $\mathrm{N}_{2} \mathrm{O}_{5}$ (Palm et al., 2017). We discuss below how to avoid significant VOC oxidation by $\mathrm{NO}_{3}$ and achieve $\mathrm{OH}$-dominated VOC oxidation in OFRs with high $\mathrm{NO}$ injection.

If $\mathrm{NO}_{3} \exp / \mathrm{OH}_{\exp }>0.1, \mathrm{NO}_{3}$ can be a competitive reactant for biogenic alkenes and dihydrofurans, which have a $\mathrm{C}-\mathrm{C}$ bond for $\mathrm{NO}_{3}$ addition, and phenols, which have activated hydroxyl for fast hydrogen abstraction by $\mathrm{NO}_{3}$ (Atkinson and Arey, 2003). For lower $\mathrm{NO}_{3 \exp } / \mathrm{OH}_{\text {exp }}$, $\mathrm{OH}$ is expected to dominate the oxidation of all VOCs, as shown in Fig. 6. Oxidation for VOCs without alkene $\mathrm{C}-\mathrm{C}$ bonds and phenol hydroxyl (such as alkanes and (alkyl)benzenes) is dominated by $\mathrm{OH}$ unless $\mathrm{NO}_{3 \exp } / \mathrm{OH}_{\exp }>1000$. Despite its double bond, ethene reacts as slowly with $\mathrm{NO}_{3}$ as alkanes, likely due to lack of alkyl groups enriching the electron density on the $\mathrm{C}-\mathrm{C}$ bond, which slows $\mathrm{NO}_{3}$ addition. We calculate $\mathrm{NO}_{3 \exp } / \mathrm{OH}_{\exp }$ for OFR185-iNO and OFR254-iNO and plot histograms of this ratio in Fig. 6. Many experimental conditions lead to high enough $\mathrm{NO}_{3 \exp } / \mathrm{OH}_{\exp }$ that $\mathrm{NO}_{3}$ is a competitive sink for alkenes, while only under very extreme conditions can $\mathrm{NO}_{3}$ be a competitive sink for species without $\mathrm{C}-\mathrm{C}$ bonds. High-NO conditions in OFR185-iNO have lower $\mathrm{NO}_{3 \exp } / \mathrm{OH}_{\exp }\left(\sim 10^{-2}-10^{2}\right)$ than in OFR254- 


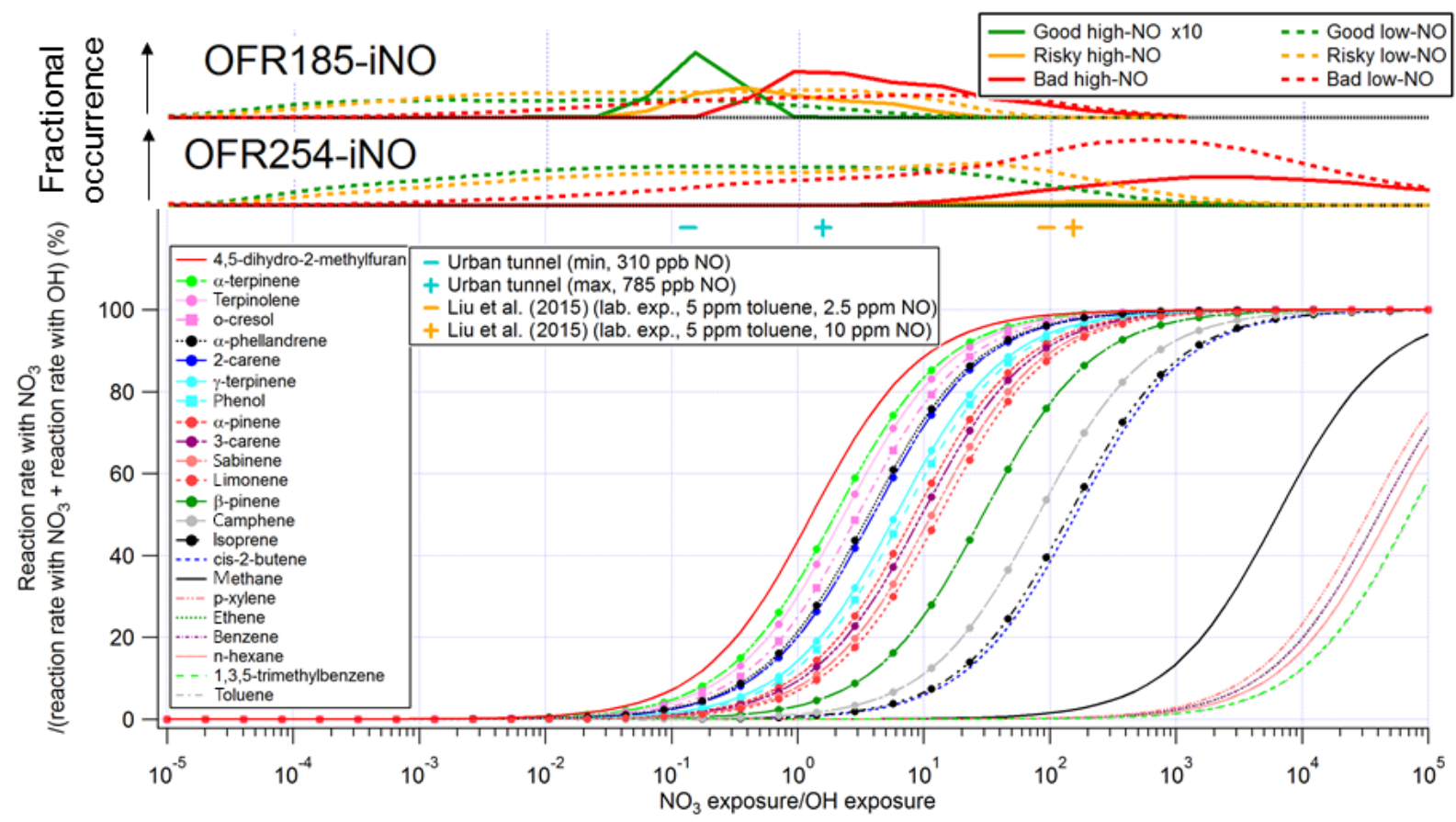

Figure 6. Fractional importance of the reaction rate of several species of interest with $\mathrm{NO}_{3}$ vs. that with $\mathrm{OH}$ as a function of the ratio of exposure to $\mathrm{NO}_{3}$ and $\mathrm{OH}$. The curves of biogenics and phenols are highlighted by solid dots and squares, respectively. The turquoise and orange markers show the ranges of modeled exposure ratios between $\mathrm{NO}_{3}$ and $\mathrm{OH}$ of a source study in an urban tunnel (Tkacik et al., 2014) and a laboratory study (Liu et al., 2015), respectively, using an OFR. In the upper part of the figure, the modeled frequency distributions of ratios of $\mathrm{NO}_{3}$ exposure to $\mathrm{OH}$ exposure under good/risky/bad high-/low-NO conditions for OFR185-iNO and OFR254-iNO are also shown. See Table 3 for the definitions of the three types of conditions. All curves, markers, and histograms in this figure share the same abscissa.

iNO $\left(\sim 10^{1}-10^{5}\right)$ (Figs. 6 and S3d, g, j). This difference in $\mathrm{NO}_{3} \exp / \mathrm{OH}_{\exp }$ is due to the different levels of $\mathrm{O}_{3}$ in the two modes, as high $\mathrm{O}_{3}$ promotes $\mathrm{NO}_{2}$-to- $\mathrm{NO}_{3}$ oxidation. Note that low-NO conditions in both OFR185-iNO and OFR254-iNO can also reach high $\mathrm{NO}_{3 \exp } / \mathrm{OH}_{\exp }$ as some high-NO conditions have. This is because in OFR185-iNO a large part of $\mathrm{NO}_{3}$ is formed by $\mathrm{OH}$ oxidation, resulting in $\mathrm{NO}_{3 \exp } / \mathrm{OH}_{\text {exp }}$ being largely influenced by $\mathrm{NO}^{\text {in }}$ but not by other factors mainly governing $\mathrm{OH}$ (Fig. S3d); under low$\mathrm{NO}$ conditions in OFR254-iNO, $\mathrm{NO}_{3}$ can form rapidly from $\mathrm{NO}_{2}+\mathrm{O}_{3}$, while $\mathrm{OH}$ can be heavily suppressed by high OHR $_{\text {ext }}$ (Fig. S3g and j).

Most of the species shown in Fig. 6 are primary VOCs, except phenols and a dihydrofuran, which can be intermediates of the atmospheric oxidation of (alkyl)benzenes (Atkinson and Arey, 2003) and long-chain alkanes (Aimanant and Ziemann, 2013; Strollo and Ziemann, 2013; Ranney and Ziemann, 2016), respectively. Nevertheless, only the phenol production may occur in high-NO OFRs, as the particle-phase reaction in the photochemical formation of dihydrofurans from alkanes is too slow compared to typical OFR residence times (Ranney and Ziemann, 2016). Therefore, the impact of $\mathrm{NO}_{3}$ oxidation on VOC fate needs to be considered only if the OFR input flow contains high NO mixed with biogenics and/or aromatics, e.g., (alkyl)benzenes and/or phenols.
However, (alkyl)benzenes were likely to be major SOA precursors in, to our knowledge, the only literature OFR studies with high NO levels (Ortega et al., 2013; Tkacik et al., 2014; Liu et al., 2015). In the study of the air in a traffic tunnel (OFR185-iNO mode; Tkacik et al., 2014), where toluene is usually a major anthropogenic SOA precursor as in other urban environments (Dzepina et al., 2009; Borbon et al., 2013; Hayes et al., 2015; Jathar et al., 2015), $\mathrm{NO}_{x}$ was several hundred ppb. This resulted in an estimated $\mathrm{NO}_{3 \exp } / \mathrm{OH}_{\text {exp }}$ range of $\sim 0.1-1$ in which up to $\sim 30 \%$ of cresols (intermediates of toluene oxidation) may have been consumed by $\mathrm{NO}_{3}$. $\mathrm{Di}-$ hydrofurans may also have formed in the tunnel air (but outside the OFR) in the presence of $\mathrm{NO}_{x}$ (Aimanant and Ziemann, 2013; Strollo and Ziemann, 2013), and after entering the OFR they would have been substantially (up to $\sim 50 \%$ ) consumed by $\mathrm{NO}_{3}$. In the laboratory experiment of Liu et al. (2015) with toluene, the injection of as much as $10 \mathrm{ppm}$ of $\mathrm{NO}$ elevated $\mathrm{NO}_{3 \exp } / \mathrm{OH}_{\text {exp }}$ to $\sim 100$, at which cresols from toluene oxidation reacted almost exclusively with $\mathrm{NO}_{3}$ in addition to being photolyzed.

\subsubsection{A case study}

We use a case study of an OFR254-13-iNO laboratory experiment with a large amount of toluene $(5 \mathrm{ppm})$ and $\mathrm{NO}^{\text {in }}$ 


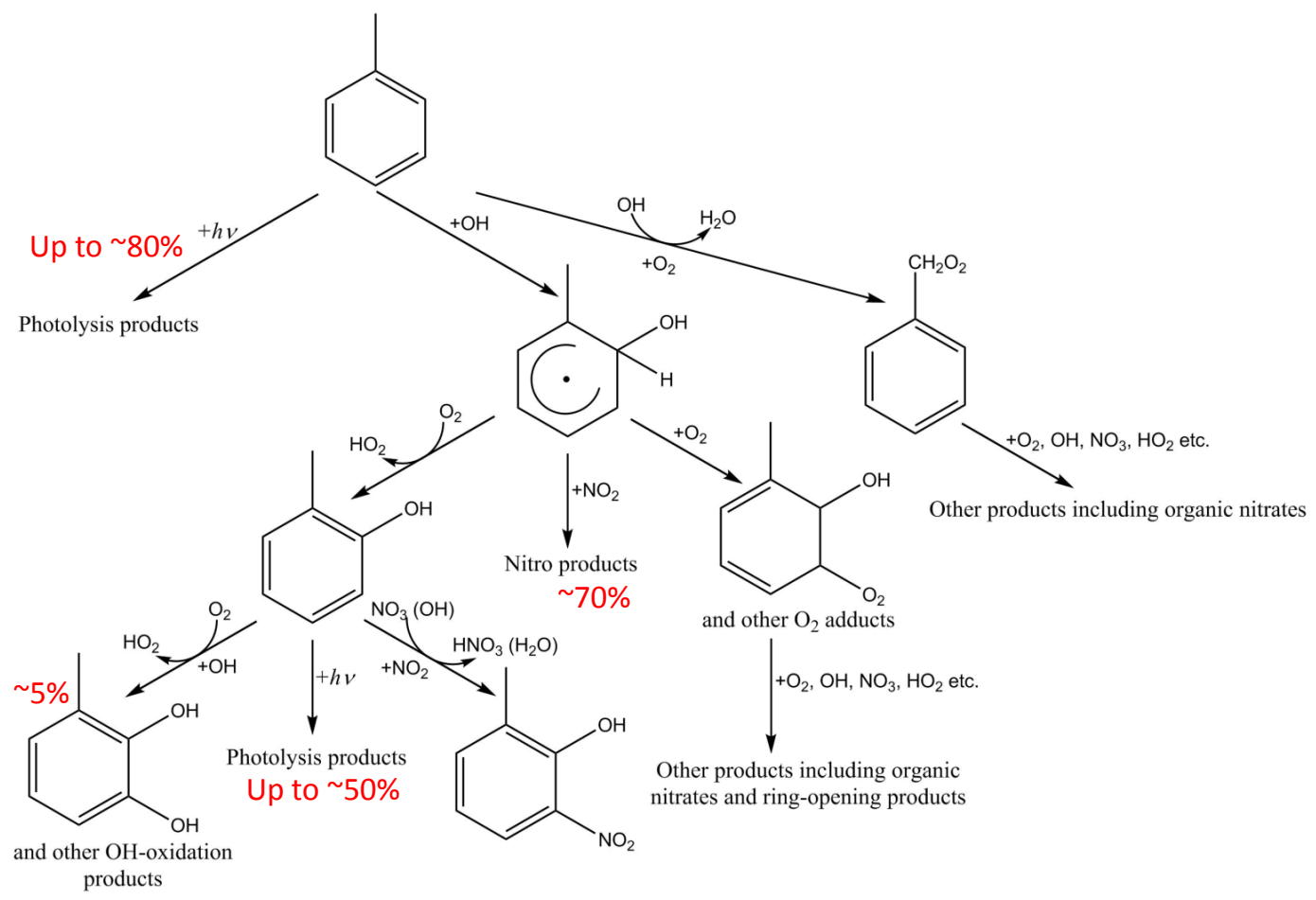

Scheme 1. Possible major reactions in an OFR254-13-iNO with 5 ppm toluene and $10 \mathrm{ppm}$ initial NO. Branching ratios in red are estimated by the model and/or according to Calvert et al. (2002), Atkinson and Arey (2003), Ziemann and Atkinson (2012), and Peng et al. (2016). Note that addition or substitution on the aromatic ring may occur at other positions. Intermediates and products shown here are the isomers that are most likely to form. Branching ratios shown in red are not overall but from immediate reactant.

(10 ppm) to illustrate how very high VOC and NO concentrations cause multiple types of atmospherically irrelevant reactions in an OFR. Due to very high $\mathrm{OHR}_{\text {ext }}$ and $\mathrm{NO}^{\text {in }}$, the photolysis of toluene at $254 \mathrm{~nm}$ may have been important (Peng et al., 2016). In the case of a high (close to 1) quantum yield, up to $\sim 80 \%$ of the consumed toluene in their experiments could have been photolyzed (Scheme 1). Of the rest of reacted toluene, $\sim 10 \%$ undergoes $\mathrm{H}$ abstraction by $\mathrm{OH}$ from the methyl group in the model, leading to an $\mathrm{RO}_{2}$ similar to alkyl $\mathrm{RO}_{2}$ and likely proceeding with normal $\mathrm{RO}_{2}$ chemistry. Approximately $90 \%$ of the toluene formed an $\mathrm{OH}$ adduct (Calvert et al., 2002). As discussed above, $70 \%$ of this adduct (depending on $\mathrm{NO}^{\text {in }}$ ) is predicted to recombine with $\mathrm{NO}_{2}$, producing nitroaromatics because of the ppm level $\mathrm{NO}_{x}$. The adduct could also react with $\mathrm{O}_{2}$ via two types of pathways, one of which was addition forming a special category of $\mathrm{RO}_{2}\left(\mathrm{OH}\right.$-toluene- $\mathrm{O}_{2}$ adducts) potentially undergoing ring-opening (Atkinson and Arey, 2003; Orlando and Tyndall, 2012; Ziemann and Atkinson, 2012). The other was $\mathrm{H}$ elimination by $\mathrm{O}_{2}$, producing cresols. Again, like toluene, cresols may have been substantially photolyzed. As a result of $\mathrm{NO}_{3 \exp } / \mathrm{OH}_{\exp } \sim 100$, only a minor portion of cresol could have undergone $\mathrm{OH}$ addition and then $\mathrm{H}$ elimination again. This pathway leads to the formation of methyldihydroxybenzenes and other OH-oxidation products (Atkinson and Arey,
2003). The rest of the cresols may have formed methylphenoxy radicals but nevertheless dominantly via $\mathrm{H}$ abstraction by $\mathrm{NO}_{3}$, since $\mathrm{H}$ abstraction by $\mathrm{OH}$ was a minor pathway compared to the $\mathrm{OH}$-addition one (Atkinson et al., 1992). In summary, the model results suggest that there were two possible routes leading to nitroaromatic formation. However, one of them (recombination of $\mathrm{OH}$-aromatic adducts with $\mathrm{NO}_{2}$ ) is likely of little atmospheric relevance due to very high $\mathrm{NO}_{x}$ needed, and the other $(\mathrm{H}$ abstraction from cresol) occurs in the atmosphere but is not a major fate of aromatics (Calvert et al., 2002).

\subsection{Implications for OFR experiments with combustion emissions as input}

Emissions from combustion sources, e.g., vehicles and biomass burning, usually contain VOCs and $\mathrm{NO}_{x}$ at very high concentrations (Table 1). An injection of this type of emissions (typically with $\mathrm{OHR}_{\mathrm{ext}}$ of thousands of $\mathrm{s}^{-1}$ or larger and $\mathrm{NO}^{\text {in }}$ of tens of ppm or larger) in OFRs without any pretreatment is likely to cause all experimental issues discussed in Peng et al. (2016) and this paper, i.e., strong $\mathrm{OH}$ suppression, substantial non-tropospheric photolysis, strong $\mathrm{RO}_{2}$ suppression by $\mathrm{NO}_{2}$ whether $\mathrm{RO}_{2}$ is acyl $\mathrm{RO}_{2}$ or not, fast reactions of $\mathrm{NO}_{2}$ with $\mathrm{OH}$-aromatic hydrocarbon adducts, substantial $\mathrm{NO}_{3}$ contribution to VOC fate, 


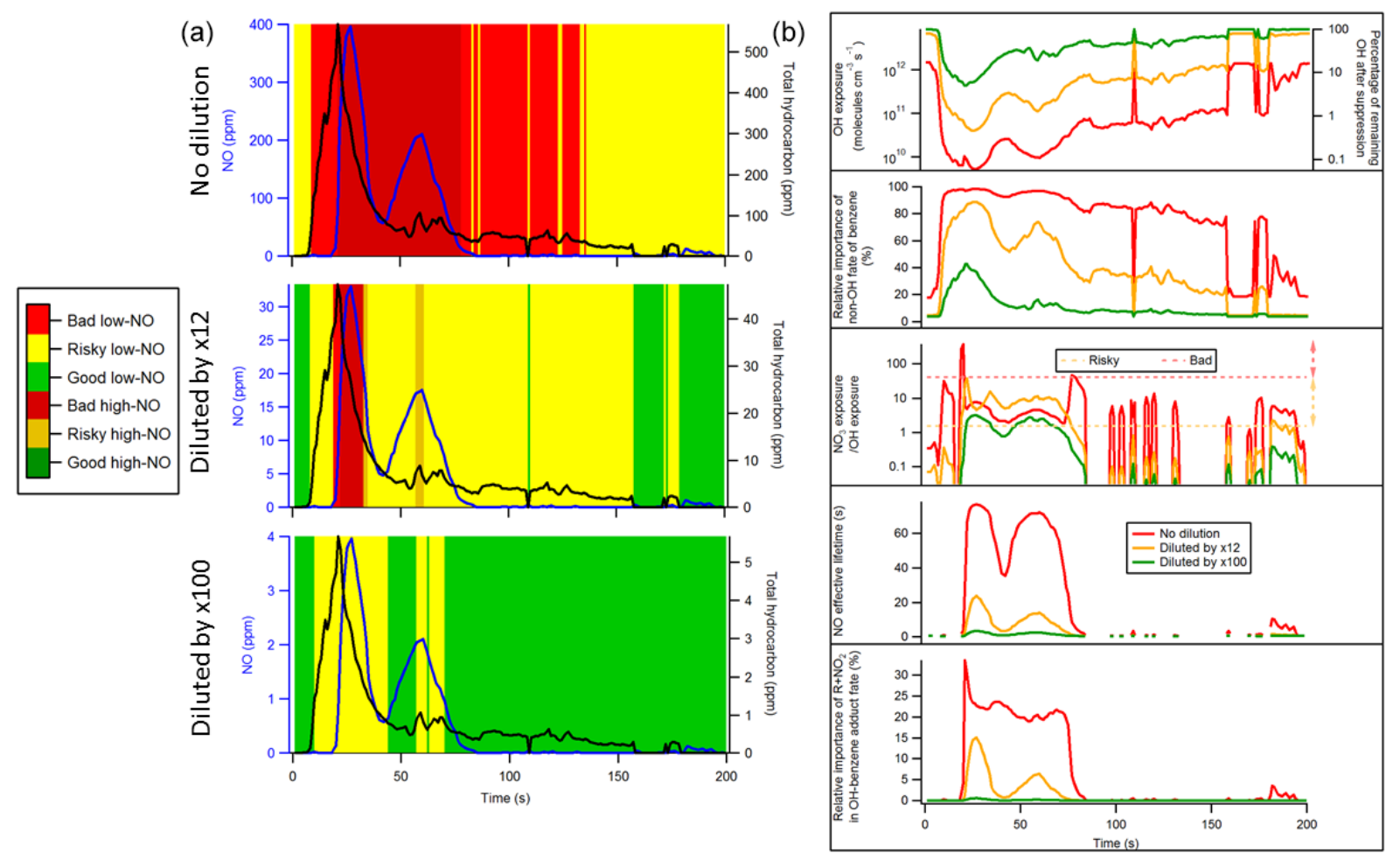

Figure 7. (a) NO and total hydrocarbon during the first $200 \mathrm{~s}$ of the test of Karjalainen et al. (2016) in the cases of no dilution, dilution by a factor of 12 (as actually done in that study), and dilution by a factor of 100. Different periods of time are colored according to corresponding emissions (i.e., input conditions for OFR) classified as good/risky/bad high-/low-NO emissions. (b) OH exposure and percentage of remaining $\mathrm{OH}$ after suppression, relative importance of non- $\mathrm{OH}$ fate of benzene, exposure ratio of $\mathrm{NO}_{3}$ to $\mathrm{OH}$, NO effective lifetime, and relative importance of reaction of $\mathrm{OH}$-toluene adduct with $\mathrm{NO}_{2}$ in the fate of this adduct in the OFR of Karjalainen et al. (2016) during the first 200 s of their test in the cases of no dilution, dilution by a factor of 12, and dilution by a factor of 100 . Horizontal orange and red dashed lines in the middle right panel denote "risky" and "bad" regions for exposure ratio of $\mathrm{NO}_{3}$ to $\mathrm{OH}$, respectively. Above the orange (red) dashed line, reaction with $\mathrm{NO}_{3}$ contributes $>20 \%$ to the fate of phenol (isoprene).

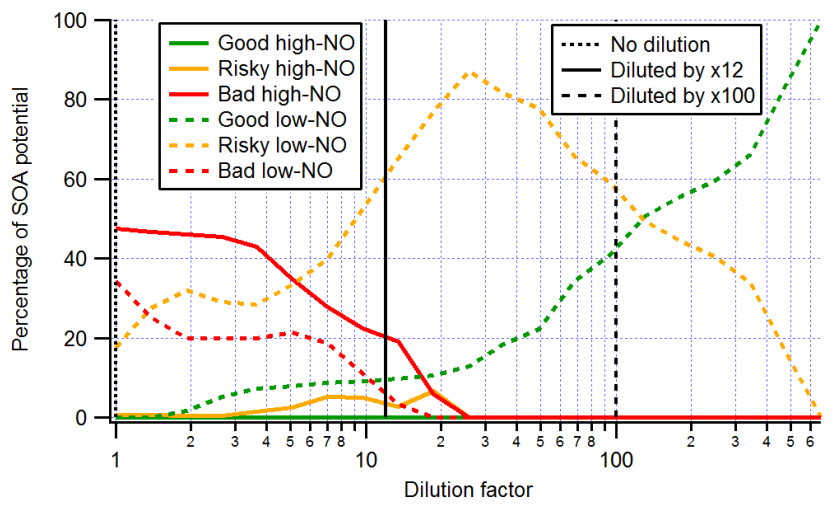

Figure 8. Secondary organic aerosol (SOA) potential (estimated from the total hydrocarbon measurement) in the OFR of Karjalainen et al. (2016) formed during periods of time in the OFR corresponding to good/risky/bad high-/low-NO conditions as a function of dilution factor. Vertical lines denoting dilution factors of 1, 12 (as actually used in that study), and 100 are also shown. and even a nearly total inhibition of OFR chemistry due to complete titration of $\mathrm{O}_{3}$ by $\mathrm{NO}$ in the case of OFR254. We take the study of Karjalainen et al. (2016), who used an OFR to oxidize diluted car exhaust in real time, as a case study to investigate the extent to which these issues may affect typical combustion source studies and to explore approaches to mitigate the problems.

During the first $200 \mathrm{~s}$ of their experiment (defined as the "cold start" period when the catalyst is cold and emissions are high), NO and total hydrocarbon in the emissions of the test vehicle reached $\sim 400$ and $\sim 600 \mathrm{ppm}$, respectively. We first simulate the oxidation of those emissions without any dilution (even though $\times 12$ dilution was used in their experiments) to explore the most extreme conditions. Our model simulation indicates that such an extremely concentrated source would generally lead to bad high- or low-NO conditions (depending on NO concentration) in their OFR (Fig. 7), even though it was run at relatively high $\mathrm{H}_{2} \mathrm{O}$ and UV. OH suppression can be as high as 3 orders of magnitude, VOC fates by non-tropospheric photolysis and reactions of alkenes and phenols with $\mathrm{NO}_{3}$ can be nearly $100 \%$, 


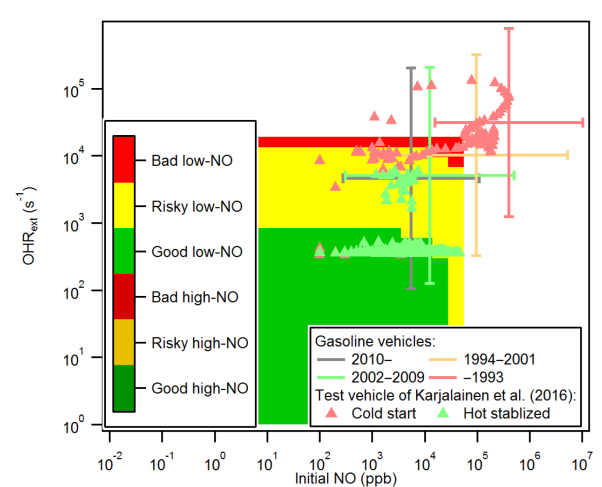

(a) No dilution (background: case $\mathrm{HH}$ )

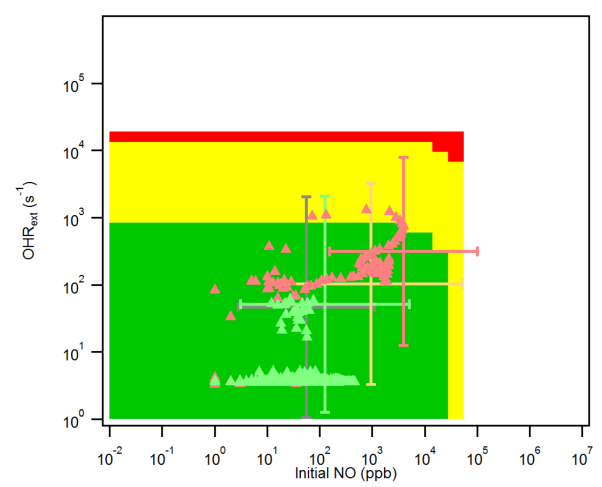

(b) Dilution by a factor of 100 (background: case $\mathrm{HH}$ )

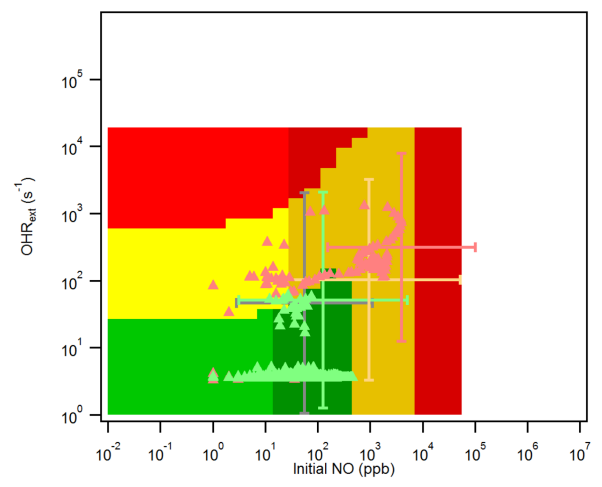

(c) Dilution by a factor of $\mathbf{1 0 0}$ (background: case $\mathrm{HL}$ )

Figure 9. Location of individual $1 \mathrm{~s}$ data points vs. OFR185-iNO reaction conditions. Data points are shown from the test vehicle of Karjalainen et al. (2016) and average exhaust from gasoline vehicle on-road emissions measured by Bishop and Stedman (2013). Onroad emissions are classified by vehicle year and the distribution of each category is shown as a cross representing 1 SD (standard deviation; with lognormal distribution assumed). The $x$ and $y$ axes are $\mathrm{NO}$ and external $\mathrm{OH}$ reactivity (excluding $\mathrm{N}$-containing species) due to vehicle emissions in an OFR in the cases of (a) no dilution and (b, c) dilution by a factor of 100. The Karjalainen et al. (2016) points are classified as cold start (during the first 200s) and hot stabilized (during 200-1000 s). In addition, the same image plots as the panels of cases $\mathrm{HH}$ (high $\mathrm{H}_{2} \mathrm{O}$ and high UV; see Table 2 for the case label code) and HL in Fig. 4 (OFR185-iNO) are shown as background for comparison. and up to $\sim 1 / 3$ of $\mathrm{OH}$-toluene adduct may be recombined with $\mathrm{NO}_{2}$ instead of forming an adduct with $\mathrm{O}_{2}$. After the test vehicle entered the "hot stabilized" stage (200-1000 s), its VOC emissions (on the order of ppm) were still too high for an undiluted OFR to yield a good condition (Fig. S9). $\mathrm{OH}$ suppression can still reach 2 orders of magnitude, nontropospheric photolysis and sometimes reactions with $\mathrm{NO}_{3}$ can still dominate over reactions with $\mathrm{OH}$ in VOC fates, and reactions of $\mathrm{OH}$-toluene adduct with $\mathrm{NO}_{2}$ can still be substantial at some small NO emission spikes. Moreover, although NO emissions were roughly at ppm level even during the hot stabilized period, the NO effective lifetime may be very short during that period, leading to low-NO conditions in their OFR.

As suggested in Peng et al. (2016) for a low-NO OFR, the dilution of sources can also mitigate strong deviations in OFR-iNO chemistry vs. atmospherically relevant conditions. A dilution by a factor of 12, as actually used by Karjalainen et al. (2016), appears to be sufficient to bring most of the hot stabilized period under good conditions (Fig. S9). However, most VOC, or in other words most SOA formation potential, was emitted during the cold start period when risky and bad conditions still prevailed (Figs. 7 and 8). Even if the emissions are diluted by $\times 100$, the cold-start emission peak (Fig. 7) is still under risky conditions. Although bad conditions are eliminated and a good condition is present most of time, this emission peak under risky conditions may contribute $>50 \%$ to total SOA formation potential (Fig. 8). For SOA formed under good condition to be dominant, a dilution factor of $>400$ would be needed. Note that a strong dilution lowers aerosol mass loading in vehicle emissions. As a result, the condensation of gases onto particles is slower than in raw exhausts. However, condensational sinks after dilution may still be significantly higher than typical ambient values (Matti Maricq, 2007; Donahue et al., 2016).

Note that the emissions of the test vehicle of Karjalainen et al. (2016) are rather clean compared to the typical 2013 US on-road fleet (i.e., all at the hot stabilized stage) measured by Bishop and Stedman (2013; Figs. 9 and S10). For the emissions of an average on-road fleet, a dilution by a factor of 100 or larger would be necessary to ensure that most emissions are processed in OFR185 under good conditions at the highest $\mathrm{H}_{2} \mathrm{O}$ and UV in this study (Figs. $9 \mathrm{~b}$ and $\mathrm{S} 10 \mathrm{~b}, \mathrm{e}, \mathrm{h}$ ). In the case of lower $\mathrm{H}_{2} \mathrm{O}$ and/or UV, an even larger dilution factor would be required.

Conducting OFR185-iNO experiments at high UV lowers the dilution factor needed for good conditions. However, it also renders good high-NO conditions impossible (see Sect. 3.2 and Fig. S4). If one wants to oxidize vehicle exhausts in a high-NO environment in an OFR, as in an urban atmosphere, OFR185 at low UV is necessary. Consequently, a much stronger dilution is in turn necessary to keep the operation conditions good. Nevertheless, not all vehicle emissions can be moved into the good high-NO region through a simple dilution (Figs. 9c and S10c, f, i). Further- 
more, a low UV would seriously limit the highest $\mathrm{OH}_{\exp }$ that OFRs can achieve $\left(\sim 3 \times 10^{11}\right.$ molecules $\mathrm{cm}^{-3}$ s for modeled good high-NO conditions in this study), while a much higher $\mathrm{OH}_{\text {exp }}$ would be desirable to fully convert SOA formation potential into measurable SOA mass. If both good high-NO conditions and high $\mathrm{OH}_{\text {exp }}$ are required, new techniques (e.g., injection of $\mathrm{N}_{2} \mathrm{O}$ at the percent level as proposed by Lambe et al., 2017) may be necessary.

\section{Conclusions}

In this study, OFR chemistry involving $\mathrm{NO}_{y}$ species was systematically investigated over a wide range of conditions. NO initially injected into the OFR was found to be rapidly oxidized under most conditions. In particular, due to high $\mathrm{O}_{3}$ concentrations, the NO lifetime in OFR254-iNO was too short to result in significant $\mathrm{RO}_{2}$ consumption by $\mathrm{NO}$ compared to that by $\mathrm{HO}_{2}$ under all conditions with active chemistry. Nevertheless, it is not completely impossible for OFR185-iNO to have a significant $\mathrm{RO}_{2}$ fate by $\mathrm{NO}$ and minor non-tropospheric photolysis at the same time (good highNO conditions). According to our simulations, these conditions are most likely present at high $\mathrm{H}_{2} \mathrm{O}$, low UV, low $\mathrm{OHR}_{\text {ext }}$, and $\mathrm{NO}^{\text {in }}$ of tens to hundreds of $\mathrm{ppb}$.

However, many past OFR studies with high NO injection were conducted under conditions remarkably different from the abovementioned very narrow range. $\mathrm{NO}^{\text {in }}$ and/or $\mathrm{OHR}_{\mathrm{ext}}$ in those studies were often much higher than good high-NO conditions require (particularly, $>3$ orders of magnitude in some OFR studies using combustion emissions as input). In addition to non-tropospheric organic photolysis, OFR oxidation of highly concentrated sources can cause multiple large deviations from tropospheric $\mathrm{OH}$ oxidation, i.e., $\mathrm{RO}_{2}$ suppression by high $\mathrm{NO}_{2}$, substantial nitroaromatic formation from the recombination of $\mathrm{NO}_{2}$ and $\mathrm{OH}$-aromatic adducts, and fast reactions of VOCs with $\mathrm{NO}_{3}$ compared to those with $\mathrm{OH}$.

Working at lower $\mathrm{NO}_{x}$ (sub ppm level) and VOC concentrations or dilution can mitigate these experimental problems. In general, a strong dilution (by a factor of $>100$ ) is needed for an OFR that processes typical on-road vehicle emissions. Humidification can also make good conditions more likely. By using these measures, good conditions can be guaranteed as long as NO and/or precursor concentrations are sufficiently low, while high-NO conditions cannot be ensured. To aid the design and interpretation of OFR experiments with high NO injection, we provide our detailed modeling results in a visualized form (Fig. S3). For OFR users in need of both high $\mathrm{OH}_{\text {exp }}$ and high NO, simple NO injection is not a good option. New techniques (e.g., the injection of $\mathrm{N}_{2} \mathrm{O}$ as proposed by Lambe et al. (2017) or other innovations) may be necessary to meet this need.
Data availability. The model outputs in this study are available from the authors upon request (jose.jimenez@colorado.edu). All data shown in the figures in this paper (including the Supplement) can be downloaded from http://cires1.colorado.edu/jimenez/group_ pubs.html.

\section{The Supplement related to this article is available online at https://doi.org/10.5194/acp-17-11991-2017- supplement.}

Competing interests. The authors declare that they have no conflict of interest.

Acknowledgements. This work was partially supported by DOE (BER/ASR) DE-SC0011105 and DE-SC0016559, EPA STAR 83587701-0, and NSF AGS-1360834. We thank Pengfei Liu, Andrew Lambe, and Daniel Tkacik for providing some OFR experimental data, the authors of Karjalainen et al. (2016) and their project IEA-AMF Annex 44 for providing the data and information for the vehicle tests, Gary Bishop for providing on-road vehicle emission data, and Andrew Lambe and William Brune for useful discussions.

Edited by: Dwayne Heard

Reviewed by: Gordon McFiggans and one anonymous referee

\section{References}

Aimanant, S. and Ziemann, P. J.: Chemical Mechanisms of Aging of Aerosol Formed from the Reaction of n-Pentadecane with $\mathrm{OH}$ Radicals in the Presence of $\mathrm{NO}_{x}$, Aerosol Sci. Tech., 47, 979990, https://doi.org/10.1080/02786826.2013.804621, 2013.

Alanen, J., Simonen, P., Saarikoski, S., Timonen, H., Kangasniemi, O., Saukko, E., Hillamo, R., Lehtoranta, K., Murtonen, T., Vesala, H., Keskinen, J., and Rönkkö, T.: Comparison of primary and secondary particle formation from natural gas engine exhaust and of their volatility characteristics, Atmos. Chem. Phys. Discuss., https://doi.org/10.5194/acp-2017-44, in review, 2017.

Ammann, M., Cox, R. A., Crowley, J. N., Jenkin, M. E., Mellouki, A., Rossi, M. J., Troe, J., Wallington, T. J., Cox, B., Atkinson, R., Baulch, D. L., and Kerr, J. A.: IUPAC Task Group on Atmospheric Chemical Kinetic Data Evaluation, available at: http://iupac.pole-ether.fr/\# (last access: February 2017), 2016.

Atkinson, R. and Arey, J.: Atmospheric degradation of volatile organic compounds, Chem. Rev., 103, 4605-4638, https://doi.org/10.1021/cr0206420, 2003.

Atkinson, R., Aschmann, S. M., and Arey, J.: Reactions of hydroxyl and nitrogen trioxide radicals with phenol, cresols, and 2nitrophenol at 296 \pm 2 K, Environ. Sci. Technol., 26, 1397-1403, https://doi.org/10.1021/es00031a018, 1992.

BIPM, IEC, IFCC, ILAC, ISO, IUPAC and IUPAPOIML: JCGM 101: 2008 Evaluation of measurement data - Supplement 1 to the "Guide to the expression of uncertainty in measurement" - Propagation of distributions using a Monte 
Carlo method, http://www.bipm.org/utils/common/documents/ jcgm/JCGM_101_2008_E.pdf (last access: December 2016), 2008.

Bishop, G. A. and Stedman, D. H.: Fuel Efficiency Automobile Test: Light-Duty Vehicles, available at: http://www.feat. biochem.du.edu/light_duty_vehicles.html (last access: 1 February 2017), 2013.

Borbon, A., Gilman, J. B., Kuster, W. C., Grand, N., Chevaillier, S., Colomb, A., Dolgorouky, C., Gros, V., Lopez, M., Sarda-Esteve, R., Holloway, J., Stutz, J., Petetin, H., McKeen, S., Beekmann, M., Warneke, C., Parrish, D. D., and De Gouw, J. A.: Emission ratios of anthropogenic volatile organic compounds in northern mid-latitude megacities: Observations versus emission inventories in Los Angeles and Paris, J. Geophys. Res.-Atmos., 118, 2041-2057, https://doi.org/10.1002/jgrd.50059, 2013.

Burkholder, J. B., Sander, S. P., Abbatt, J., Barker, J. R., Huie, R. E., Kolb, C. E., Kurylo, M. J., Orkin, V. L., Wilmouth, D. M., and Wine, P. H.: Chemical Kinetics and Photochemical Data for Use in Atmospheric Studies, Evaluation Number 18, Pasadena, CA, USA, available at: http://jpldataeval.jpl.nasa.gov/ (last access: February 2017), 2015.

Calvert, J. G., Atkinson, R., Becker, K. H., Kamens, R. M., Seinfeld, J. H., Wallington, T. H., and Yarwood, G.: The Mechanisms of Atmospheric Oxidation of the Aromatic Hydrocarbons, Oxford University Press, USA, available at: https://books.google.com/ books?id=P0basaLrxDMC (last access: February 2017), 2002.

Carlton, A. G., Wiedinmyer, C., and Kroll, J. H.: A review of Secondary Organic Aerosol (SOA) formation from isoprene, Atmos. Chem. Phys., 9, 4987-5005, https://doi.org/10.5194/acp-9-49872009, 2009.

Carter, W. P. L., Cocker, D. R., Fitz, D. R., Malkina, I. L., Bumiller, K., Sauer, C. G., Pisano, J. T., Bufalino, C., and Song, C.: A new environmental chamber for evaluation of gas-phase chemical mechanisms and secondary aerosol formation, Atmos. Environ., 39, 7768-7788, https://doi.org/10.1016/j.atmosenv.2005.08.040, 2005.

Chameides, W., Lindsay, R., Richardson, J., and Kiang, C.: The role of biogenic hydrocarbons in urban photochemical smog: Atlanta as a case study, Science, 241, 1473-1475, https://doi.org/10.1126/science.3420404, 1988.

Cocker, D. R., Flagan, R. C., and Seinfeld, J. H.: Stateof-the-Art Chamber Facility for Studying Atmospheric Aerosol Chemistry, Environ. Sci. Technol., 35, 2594-2601, https://doi.org/10.1021/es0019169, 2001.

Donahue, N. M., Posner, L. N., Westervelt, D. M., Li, Z., Shrivastava, M., Presto, A. A., Sullivan, R. C., Adams, P. J., Pandis, S. N., and Robinson, A. L.: Where Did This Particle Come From? Sources of Particle Number and Mass for Human Exposure Estimates, in: Airborne Particulate Matter: Sources, Atmospheric Processes and Health, edited by: Harrison, R. M., Hester, R. E., and Querol, X., Royal Society of Chemistry, Cambridge, UK, 35-71, 2016.

Dzepina, K., Volkamer, R. M., Madronich, S., Tulet, P., Ulbrich, I. M., Zhang, Q., Cappa, C. D., Ziemann, P. J., and Jimenez, J. L.: Evaluation of recently-proposed secondary organic aerosol models for a case study in Mexico City, Atmos. Chem. Phys., 9, 5681-5709, https://doi.org/10.5194/acp-9-5681-2009, 2009.

George, I. J., Vlasenko, A., Slowik, J. G., Broekhuizen, K., and Abbatt, J. P. D.: Heterogeneous oxidation of saturated organic aerosols by hydroxyl radicals: uptake kinetics, condensed-phase products, and particle size change, Atmos. Chem. Phys., 7, 41874201, https://doi.org/10.5194/acp-7-4187-2007, 2007.

Haagen-Smit, A. J.: Chemistry and Physiology of Los Angeles Smog, Ind. Eng. Chem., 44, 1342-1346, https://doi.org/10.1021/ie50510a045, 1952.

Hallquist, M., Wenger, J. C., Baltensperger, U., Rudich, Y., Simpson, D., Claeys, M., Dommen, J., Donahue, N. M., George, C., Goldstein, A. H., Hamilton, J. F., Herrmann, H., Hoffmann, T., Iinuma, Y., Jang, M., Jenkin, M. E., Jimenez, J. L., Kiendler-Scharr, A., Maenhaut, W., McFiggans, G., Mentel, Th. F., Monod, A., Prévôt, A. S. H., Seinfeld, J. H., Surratt, J. D., Szmigielski, R., and Wildt, J.: The formation, properties and impact of secondary organic aerosol: current and emerging issues, Atmos. Chem. Phys., 9, 5155-5236, https://doi.org/10.5194/acp9-5155-2009, 2009.

Hayes, P. L., Carlton, A. G., Baker, K. R., Ahmadov, R., Washenfelder, R. A., Alvarez, S., Rappenglück, B., Gilman, J. B., Kuster, W. C., de Gouw, J. A., Zotter, P., Prévôt, A. S. H., Szidat, S., Kleindienst, T. E., Offenberg, J. H., Ma, P. K., and Jimenez, J. L.: Modeling the formation and aging of secondary organic aerosols in Los Angeles during CalNex 2010, Atmos. Chem. Phys., 15, 5773-5801, https://doi.org/10.5194/acp-15-5773-2015, 2015.

Hearn, J. D. and Smith, G. D.: Kinetics and Product Studies for Ozonolysis Reactions of Organic Particles Using Aerosol CIMS, J. Phys. Chem. A, 108, 10019-10029, https://doi.org/10.1021/jp0404145, 2004.

Hoffmann, T., Odum, J. R., Bowman, F., Collins, D., Klockow, D., Flagan, R. C., and Seinfeld., J. H.: Formation of Organic Aerosols from the Oxidation of Biogenic Hydrocarbons, J. Atmos. Chem., 26, 189-222, https://doi.org/10.1023/A:1005734301837, 1997.

Hu, W., Palm, B. B., Day, D. A., Campuzano-Jost, P., Krechmer, J. E., Peng, Z., de Sá, S. S., Martin, S. T., Alexander, M. L., Baumann, K., Hacker, L., Kiendler-Scharr, A., Koss, A. R., de Gouw, J. A., Goldstein, A. H., Seco, R., Sjostedt, S. J., Park, J.-H., Guenther, A. B., Kim, S., Canonaco, F., Prévôt, A. S. H., Brune, W. H., and Jimenez, J. L.: Volatility and lifetime against $\mathrm{OH}$ heterogeneous reaction of ambient isoprene-epoxydiolsderived secondary organic aerosol (IEPOX-SOA), Atmos. Chem. Phys., 16, 11563-11580, https://doi.org/10.5194/acp-16-115632016, 2016.

Jathar, S. H., Cappa, C. D., Wexler, A. S., Seinfeld, J. H., and Kleeman, M. J.: Multi-generational oxidation model to simulate secondary organic aerosol in a 3-D air quality model, Geosci. Model Dev., 8, 2553-2567, https://doi.org/10.5194/gmd-8-2553-2015, 2015.

Kang, E., Root, M. J., Toohey, D. W., and Brune, W. H.: Introducing the concept of Potential Aerosol Mass (PAM), Atmos. Chem. Phys., 7, 5727-5744, https://doi.org/10.5194/acp-7-5727-2007, 2007.

Kang, E., Toohey, D. W., and Brune, W. H.: Dependence of SOA oxidation on organic aerosol mass concentration and $\mathrm{OH}$ exposure: experimental PAM chamber studies, Atmos. Chem. Phys., 11, 1837-1852, https://doi.org/10.5194/acp-11-1837-2011, 2011.

Karjalainen, P., Timonen, H., Saukko, E., Kuuluvainen, H., Saarikoski, S., Aakko-Saksa, P., Murtonen, T., Bloss, M., Dal Maso, M., Simonen, P., Ahlberg, E., Svenningsson, B., Brune, W. H., Hillamo, R., Keskinen, J., and Rönkkö, T.: Time-resolved 
characterization of primary particle emissions and secondary particle formation from a modern gasoline passenger car, Atmos. Chem. Phys., 16, 8559-8570, https://doi.org/10.5194/acp16-8559-2016, 2016.

Krechmer, J. E., Pagonis, D., Ziemann, P. J., and Jimenez, J. L.: Quantification of Gas-Wall Partitioning in Teflon Environmental Chambers Using Rapid Bursts of Low-Volatility Oxidized Species Generated in Situ, Environ. Sci. Technol., 50, 57575765, https://doi.org/10.1021/acs.est.6b00606, 2016.

Lakey, P. S. J., George, I. J., Whalley, L. K., Baeza-Romero, M. T. and Heard, D. E.: Measurements of the $\mathrm{HO}_{2}$ Uptake Coefficients onto Single Component Organic Aerosols, Environ. Sci. Technol., 49, 4878-4885, https://doi.org/10.1021/acs.est.5b00948, 2015.

Lambe, A., Massoli, P., Zhang, X., Canagaratna, M., Nowak, J., Daube, C., Yan, C., Nie, W., Onasch, T., Jayne, J., Kolb, C., Davidovits, P., Worsnop, D., and Brune, W.: Controlled nitric oxide production via $\mathrm{O}\left({ }^{1} \mathrm{D}\right)+\mathrm{N}_{2} \mathrm{O}$ reactions for use in oxidation flow reactor studies, Atmos. Meas. Tech., 10, 2283-2298, https://doi.org/10.5194/amt-10-2283-2017, 2017.

Lambe, A. T. and Jimenez, J. L.: PAM Wiki: Publications Using the PAM Oxidation Flow Reactor, available at: https://sites.google. com/site/pamwiki/publications, last access: 27 September 2017.

Lambe, A. T., Ahern, A. T., Williams, L. R., Slowik, J. G., Wong, J. P. S., Abbatt, J. P. D., Brune, W. H., Ng, N. L., Wright, J. P., Croasdale, D. R., Worsnop, D. R., Davidovits, P., and Onasch, T. B.: Characterization of aerosol photooxidation flow reactors: heterogeneous oxidation, secondary organic aerosol formation and cloud condensation nuclei activity measurements, Atmos. Meas. Tech., 4, 445-461, https://doi.org/10.5194/amt-4445-2011, 2011.

Levy II, H.: Normal atmosphere: large radical and formaldehyde concentrations predicted, Science, 173, 141-143, https://doi.org/10.1126/science.173.3992.141, 1971.

Li, R., Palm, B. B., Borbon, A., Graus, M., Warneke, C., Ortega, A. M., Day, D. A., Brune, W. H., Jimenez, J. L., and de Gouw, J. A.: Laboratory Studies on Secondary Organic Aerosol Formation from Crude Oil Vapors, Environ. Sci. Technol., 47, 1256612574, https://doi.org/10.1021/es402265y, 2013.

Li, R., Palm, B. B., Ortega, A. M., Hu, W., Peng, Z., Day, D. A., Knote, C., Brune, W. H., de Gouw, J., and Jimenez, J. L.: Modeling the radical chemistry in an Oxidation Flow Reactor (OFR): radical formation and recycling, sensitivities, and $\mathrm{OH}$ exposure estimation equation, J. Phys. Chem. A, 119, 4418-4432, https://doi.org/10.1021/jp509534k, 2015.

Link, M. F., Friedman, B., Fulgham, R., Brophy, P., Galang, A., Jathar, S. H., Veres, P., Roberts, J. M. and Farmer, D. K.: Photochemical processing of diesel fuel emissions as a large secondary source of isocyanic acid (HNCO), Geophys. Res. Lett., 43, 40334041, https://doi.org/10.1002/2016GL068207, 2016.

Lippmann, M.: Health effects of tropospheric ozone, Environ. Sci. Technol., 25, 1954-1962, https://doi.org/10.1021/es00024a001, 1991.

Liu, P. F., Abdelmalki, N., Hung, H.-M., Wang, Y., Brune, W. H., and Martin, S. T.: Ultraviolet and visible complex refractive indices of secondary organic material produced by photooxidation of the aromatic compounds toluene and $m$-Xylene, Atmos. Chem. Phys., 15, 1435-1446, https://doi.org/10.5194/acp15-1435-2015, 2015.
Mao, J., Ren, X., Brune, W. H., Olson, J. R., Crawford, J. H., Fried, A., Huey, L. G., Cohen, R. C., Heikes, B., Singh, H. B., Blake, D. R., Sachse, G. W., Diskin, G. S., Hall, S. R., and Shetter, R. E.: Airborne measurement of $\mathrm{OH}$ reactivity during INTEX-B, Atmos. Chem. Phys., 9, 163-173, https://doi.org/10.5194/acp-9163-2009, 2009.

Martinsson, J., Eriksson, A. C., Nielsen, I. E., Malmborg, V. B., Ahlberg, E., Andersen, C., Lindgren, R., Nyström, R., Nordin, E. Z., Brune, W. H., Svenningsson, B., Swietlicki, E., Boman, C., and Pagels, J. H.: Impacts of Combustion Conditions and Photochemical Processing on the Light Absorption of Biomass Combustion Aerosol, Environ. Sci. Technol., 49, 14663-14671, https://doi.org/10.1021/acs.est.5b03205, 2015.

Matsunaga, A. and Ziemann, P. J.: Gas-Wall Partitioning of Organic Compounds in a Teflon Film Chamber and Potential Effects on Reaction Product and Aerosol Yield Measurements, Aerosol Sci. Tech., 44, 881-892, https://doi.org/10.1080/02786826.2010.501044, 2010.

Matti Maricq, M.: Chemical characterization of particulate emissions from diesel engines: A review, J. Aerosol Sci., 38, 10791118, https://doi.org/10.1016/j.jaerosci.2007.08.001, 2007.

Moise, T. and Rudich, Y.: Reactive Uptake of Ozone by Aerosol-Associated Unsaturated Fatty Acids: Kinetics, Mechanism, and Products, J. Phys. Chem. A, 106, 6469-6476, https://doi.org/10.1021/jp025597e, 2002.

Moise, T., Talukdar, R. K., Frost, G. J., Fox, R. W., and Rudich, Y.: Reactive uptake of $\mathrm{NO}_{3}$ by liquid and frozen organics, J. Geophys. Res., 107, 4014, https://doi.org/10.1029/2001JD000334, 2002.

Nehr, S., Bohn, B., Fuchs, H., Häseler, R., Hofzumahaus, A., Li, X., Rohrer, F., Tillmann, R., and Wahner, A.: Atmospheric photochemistry of aromatic hydrocarbons: $\mathrm{OH}$ budgets during SAPHIR chamber experiments, Atmos. Chem. Phys., 14, 69416952, https://doi.org/10.5194/acp-14-6941-2014, 2014.

Nel, A.: Air Pollution-Related Illness: Effects of Particles, Science, 308, 804-806, https://doi.org/10.1126/science.1108752, 2005.

Ng, N. L., Canagaratna, M. R., Zhang, Q., Jimenez, J. L., Tian, J., Ulbrich, I. M., Kroll, J. H., Docherty, K. S., Chhabra, P. S., Bahreini, R., Murphy, S. M., Seinfeld, J. H., Hildebrandt, L., Donahue, N. M., DeCarlo, P. F., Lanz, V. A., Prévôt, A. S. H., Dinar, E., Rudich, Y., Worsnop, D. R.: Organic aerosol components observed in Northern Hemispheric datasets from Aerosol Mass Spectrometry, Atmos. Chem. Phys., 10, 46254641, https://doi.org/10.5194/acp-10-4625-2010, 2010.

Odum, J. R., Hoffmann, T., Bowman, F., Collins, D., Flagan Richard, C., and Seinfeld, J. H.: Gas particle partitioning and secondary organic aerosol yields, Environ. Sci. Technol., 30, 25802585, https://doi.org/10.1021/es950943+, 1996.

Orlando, J. J. and Tyndall, G. S.: Laboratory studies of organic peroxy radical chemistry: an overview with emphasis on recent issues of atmospheric significance, Chem. Soc. Rev., 41, 6294, https://doi.org/10.1039/c2cs35166h, 2012.

Ortega, A. M., Day, D. A., Cubison, M. J., Brune, W. H., Bon, D., de Gouw, J. A., and Jimenez, J. L.: Secondary organic aerosol formation and primary organic aerosol oxidation from biomassburning smoke in a flow reactor during FLAME-3, Atmos. Chem. Phys., 13, 11551-11571, https://doi.org/10.5194/acp-1311551-2013, 2013. 
Ortega, A. M., Hayes, P. L., Peng, Z., Palm, B. B., Hu, W., Day, D. A., Li, R., Cubison, M. J., Brune, W. H., Graus, M., Warneke, C., Gilman, J. B., Kuster, W. C., de Gouw, J., GutiérrezMontes, C., and Jimenez, J. L.: Real-time measurements of secondary organic aerosol formation and aging from ambient air in an oxidation flow reactor in the Los Angeles area, Atmos. Chem. Phys., 16, 7411-7433, https://doi.org/10.5194/acp16-7411-2016, 2016.

Palm, B. B., Campuzano-Jost, P., Ortega, A. M., Day, D. A., Kaser, L., Jud, W., Karl, T., Hansel, A., Hunter, J. F., Cross, E. S., Kroll, J. H., Peng, Z., Brune, W. H., and Jimenez, J. L.: In situ secondary organic aerosol formation from ambient pine forest air using an oxidation flow reactor, Atmos. Chem. Phys., 16, 29432970, https://doi.org/10.5194/acp-16-2943-2016, 2016.

Palm, B. B., Campuzano-Jost, P., Day, D. A., Ortega, A. M., Fry, J. L., Brown, S. S., Zarzana, K. J., Dube, W., Wagner, N. L., Draper, D. C., Kaser, L., Jud, W., Karl, T., Hansel, A., GutiérrezMontes, C. and Jimenez, J. L.: Secondary organic aerosol formation from in situ $\mathrm{OH}, \mathrm{O}_{3}$, and $\mathrm{NO}_{3}$ oxidation of ambient forest air in an oxidation flow reactor, Atmos. Chem. Phys., 17, 53315354, https://doi.org/10.5194/acp-17-5331-2017, 2017.

Peng, Z., Carrasco, N., and Pernot, P.: Modeling of synchrotron-based laboratory simulations of Titan's ionospheric photochemistry, Geo. Res. J., 1-2, 33-53, https://doi.org/10.1016/j.grj.2014.03.002, 2014.

Peng, Z., Day, D. A., Ortega, A. M., Palm, B. B., Hu, W., Stark, H., Li, R., Tsigaridis, K., Brune, W. H., and Jimenez, J. L.: Non-OH chemistry in oxidation flow reactors for the study of atmospheric chemistry systematically examined by modeling, Atmos. Chem. Phys., 16, 4283-4305, https://doi.org/10.5194/acp16-4283-2016, 2016.

Peng, Z., Day, D. A., Stark, H., Li, R., Lee-Taylor, J., Palm, B. B., Brune, W. H., and Jimenez, J. L.: $\mathrm{HO}_{x}$ radical chemistry in oxidation flow reactors with low-pressure mercury lamps systematically examined by modeling, Atmos. Meas. Tech., 8, 4863-4890, https://doi.org/10.5194/amt-8-4863-2015, 2015.

Ranney, A. P. and Ziemann, P. J.: Kinetics of Acid-Catalyzed Dehydration of Cyclic Hemiacetals in Organic Aerosol Particles in Equilibrium with Nitric Acid Vapor, J. Phys. Chem. A, 120, 2561-2568, https://doi.org/10.1021/acs.jpca.6b01402, 2016.

Richards-Henderson, N. K., Goldstein, A. H., and Wilson, K. R.: Large Enhancement in the Heterogeneous Oxidation Rate of Organic Aerosols by Hydroxyl Radicals in the Presence of Nitric Oxide, J. Phys. Chem. Lett., 6, 4451-4455, https://doi.org/10.1021/acs.jpclett.5b02121, 2015.

Saltelli, A., Ratto, M., Tarantola, S., and Campolongo, F.: Sensitivity Analysis for Chemical Models, Chem. Rev., 105, 2811-2828, https://doi.org/10.1021/cr040659d, 2005.

Sander, S. P., Friedl, R. R., Barker, J. R., Golden, D. M., Kurylo, M. J., Wine, P. H., Abbatt, J. P. D., Burkholder, J. B., Kolb, C. E., Moortgat, G. K., Huie, R. E., and Orkin, V. L.: Chemical Kinetics and Photochemical Data for Use in Atmospheric Studies, Evaluation Number 7, Pasadena, CA, USA, available at: http://jpldataeval.jpl.nasa.gov/pdf/JPL10-6Final (last access: June 2016), 2011.
Schill, G. P., Jathar, S. H., Kodros, J. K., Levin, E. J. T., Galang, A. M., Friedman, B., Link, M. F., Farmer, D. K., Pierce, J. R., Kreidenweis, S. M., and DeMott, P. J.: Icenucleating particle emissions from photochemically aged diesel and biodiesel exhaust, Geophys. Res. Lett., 43, 5524-5531, https://doi.org/10.1002/2016GL069529, 2016.

Schwantes, R. H., Schilling, K. A., McVay, R. C., Lignell, H., Coggon, M. M., Zhang, X., Wennberg, P. O., and Seinfeld, J. H.: Formation of highly oxygenated low-volatility products from cresol oxidation, Atmos. Chem. Phys., 17, 3453-3474, https://doi.org/10.5194/acp-17-3453-2017, 2017.

Seakins, P. W.: A brief review of the use of environmental chambers for gas phase studies of kinetics, chemical mechanisms and characterisation of field instruments, EPJ Web Conf., 9, 143-163, https://doi.org/10.1051/epjconf/201009012, 2010.

Simonen, P., Saukko, E., Karjalainen, P., Timonen, H., Bloss, M., Aakko-Saksa, P., Rönkkö, T., Keskinen, J., and Dal Maso, M.: A new oxidation flow reactor for measuring secondary aerosol formation of rapidly changing emission sources, Atmos. Meas. Tech., 10, 1519-1537, https://doi.org/10.5194/amt10-1519-2017, 2017.

Stocker, T. F., Qin, D., Plattner, G.-K., Tignor, M., Allen, S. K., Boschung, J., Nauels, A., Xia, Y., Bex, V., and Midgley, P. M.: Climate Change 2013 - The Physical Science Basis, edited by: Intergovernmental Panel on Climate Change, Cambridge University Press, Cambridge, 2014.

Strollo, C. M. and Ziemann, P. J.: Products and mechanism of secondary organic aerosol formation from the reaction of 3-methylfuran with $\mathrm{OH}$ radicals in the presence of $\mathrm{NO}_{x}$, Atmos. Environ., 77, 534-543, https://doi.org/10.1016/j.atmosenv.2013.05.033, 2013.

Tkacik, D. S., Lambe, A. T., Jathar, S., Li, X., Presto, A. A., Zhao, Y., Blake, D., Meinardi, S., Jayne, J. T., Croteau, P. L., and Robinson, A. L.: Secondary Organic Aerosol Formation from in-Use Motor Vehicle Emissions Using a Potential Aerosol Mass Reactor, Environ. Sci. Technol., 48, 11235-11242, https://doi.org/10.1021/es502239v, 2014.

Volkamer, R., Jimenez, J. L., San Martini, F., Dzepina, K., Zhang, Q., Salcedo, D., Molina, L. T., Worsnop, D. R., and Molina, M. J.: Secondary organic aerosol formation from anthropogenic air pollution: Rapid and higher than expected, Geophys. Res. Lett., 33, L17811, https://doi.org/10.1029/2006GL026899, 2006.

Wang, J., Doussin, J. F., Perrier, S., Perraudin, E., Katrib, Y., Pangui, E., and Picquet-Varrault, B.: Design of a new multi-phase experimental simulation chamber for atmospheric photosmog, aerosol and cloud chemistry research, Atmos. Meas. Tech., 4, 2465-2494, https://doi.org/10.5194/amt-4-2465-2011, 2011.

Zhang, X., Cappa, C. D., Jathar, S. H., McVay, R. C., Ensberg, J. J., Kleeman, M. J., and Seinfeld, J. H.: Influence of vapor wall loss in laboratory chambers on yields of secondary organic aerosol, P. Natl. Acad. Sci. USA, 111, 5802-5807, https://doi.org/10.1073/pnas.1404727111, 2014.

Ziemann, P. J. and Atkinson, R.: Kinetics, products, and mechanisms of secondary organic aerosol formation, Chem. Soc. Rev., 41, 6582, https://doi.org/10.1039/c2cs35122f, 2012. 